\title{
Synthesis and Biological Activity of $N^{4}$-phenylsubstituted-6-(2,4- dichloro phenylmethyl)-7H-pyrrolo[2,3-d]pyrimidine-2,4-diamines as Vascular Endothelial Growth Factor Receptor-2 Inhibitors and Antiangiogenic and Antitumor Agents
}

\author{
Aleem Gangjee ${ }^{\dagger,}{ }^{\star}$, Sonali Kurup ${ }^{\dagger}$, Michael A Ihnat ${ }^{\ddagger}$, Jessica E. Thorpe ${ }^{\ddagger}$, and Satyendra S. \\ Shenoy $\ddagger$ \\ † Division of Medicinal Chemistry, Graduate School of Pharmaceutical Sciences, Duquesne \\ University, Pittsburgh, PA 15282 \\ ‡ Department of Cell Biology, University of Oklahoma Health Science Center, Oklahoma City, OK \\ 73104
}

\begin{abstract}
A series of eight $N^{4}$-phenylsubstituted-6-(2,4-dichlorophenylmethyl)-7 $H$-pyrrolo[2,3- $d$ ] pyrimidine-2,4-diamines 8-15 were synthesized as vascular endothelial growth factor receptor-2 (VEGFR-2) inhibitors with varied substitutions in the phenyl ring of the 4-anilino moiety. In addition, five $N^{4}$-phenylsubstituted-6-phenylmethylsubstituted-7H-pyrrolo[2,3- $d$ ]pyrimidin-4-amines 16-20 were synthesized to evaluate the importance of the $2-\mathrm{NH}_{2}$ moiety for multiple receptor tyrosine kinase (RTK) inhibition. Cyclocondensation of $\alpha$-halomethylbenzylketones with 2,6-diamino-4hydroxypyrimidine afforded 2-amino-6-(2,4-dichlorophenylmethyl)-3,7-dihydro-4H-pyrrolo[2,3- $d$ ] pyrimidin-4-one, $\mathbf{2 3}$ and reaction of $\alpha$-bromomethylbenzylketones with ethylamidinoacetate followed by cyclocondensation with formamide afforded the 6- phenylmethylsubstituted-3,7dihydro-4H-pyrrolo[2,3- $d$ ] pyrimidin-4-ones, 40-42 respectively. Chlorination of the 4-position and displacement with appropriate anilines afforded the target compounds 8-20. Compounds 8, 10 and 14 were potent VEGFR-2 inhibitors and were 100-fold, 40-fold and 8-fold more potent than the standard semaxanib, respectively. Previously synthesized multiple RTK inhibitor, $\mathbf{5}$ and the VEGFR-2 inhibitor $\mathbf{8}$ from this study, were chosen for further evaluation in a mouse orthotopic model of melanoma and showed significant inhibition of tumor growth, angiogenesis and metastasis.
\end{abstract}

\section{Keywords}

Pyrrolo[2,3-d]pyrimidines; Receptor tyrosine kinase inhibitors; Antiangiogenic agents; Antitumor agents

\footnotetext{
*To whom correspondence should be addressed. Phone: 412-396-6070. Fax: 412-396-5593. gangjee@duq.edu. Supporting Material

Elemental analysis is available online.

Publisher's Disclaimer: This is a PDF file of an unedited manuscript that has been accepted for publication. As a service to our customers we are providing this early version of the manuscript. The manuscript will undergo copyediting, typesetting, and review of the resulting proof before it is published in its final citable form. Please note that during the production process errors may be discovered which could affect the content, and all legal disclaimers that apply to the journal pertain.
} 


\section{Introduction}

Receptor tyrosine kinases (RTKs) such as epidermal growth factor receptor (EGFR), vascular endothelial growth factor receptor (VEGFR) and platelet-derived growth factor receptor (PDGFR) have important functions in signal transduction pathways that regulate cell proliferation, differentiation and growth under normal cell function, as well as under abnormal conditions. ${ }^{1}, 2$ RTKs are overexpressed in several tumors and are associated with aberrant signaling leading to increased angiogenesis, tumor cell proliferation and metastasis. 1,2

Angiogenesis is the growth of new blood vessels from existing vasculature. 3 Physiological angiogenesis occurs during wound healing, the menstrual cycle and pregnancy, and produces well ordered vascular structures with mature, functional blood vessels.3,4 Pathological angiogenesis is associated with tumor growth and several diseases such as psoriasis, diabetic retinopathies and endometriosis. ${ }^{3}$ Angiogenesis is crucial for the sustained growth of tumors. The new blood vessels provide nutrients and oxygen for tumor proliferation, and also a route for metastasis. In addition to providing tumors with oxygen and nutrients through angiogenesis, activated endothelial cells release growth factors such as platelet-derived growth factor (PDGF), and insulin-like growth factor-1 (IGF-1) that on binding to the growth factor receptors activate RTKs that both maintain the endothelial cell activation and stimulate tumor cell growth. ${ }^{3-} 6$

Thus, inhibition of tumor angiogenesis offers a therapeutic strategy for treating a variety of cancers. Antiangiogenic agents are usually cytostatic and prevent the growth of the tumor but are not usually tumoricidal and are much more successful in cancer chemotherapy when combined with cytotoxic agents. ${ }^{4-6}$ Among the RTKs implicated in tumor progression are members of the VEGFR family that include VEGFR-1 and VEGFR-2, members of the EGFR family and members of the PDGFR family namely PDGFR- $\alpha$ and PDGFR- $\beta .^{7,8}$

Angiogenesis is facilitated by a number of growth factor receptors of which VEGFR-2 is the key. ${ }^{5,9-11}$ VEGF stimulation is sufficient to induce tumor growth and metastases. Inhibition of VEGFR-2 leads to an inhibition of angiogenesis, decreased vascular permeability and decreased endothelial cell survival. ${ }^{11}$

Several small molecule inhibitors of RTKs that target the adenosine triphosphate (ATP) binding site of tyrosine kinases are in clinical use and several others are in clinical trials as antitumor agents. ${ }^{1}, 2$, 12 Initial strategies for RTK inhibition focused on single RTK inhibitors such as erlotinib, $\mathbf{1}$ and gefitinib, $\mathbf{2}$ (Figure 1) that were approved for non small cell lung cancer. ${ }^{12,13}$ However, tumors have redundant signaling pathways for angiogenesis and often develop resistance to agents that target one specific pathway. ${ }^{14,15}$ A multifaceted approach that targets multiple signaling pathways has shown to be more effective than the inhibition of a single target due to the probable synergism/potentiation/additive effects that could lower the drug dose required. ${ }^{16-20}$ Multiple RTK inhibitors, sorafenib, 3 (Figure 1) an inhibitor of VEGFR, PDGFR and Raf-1 kinase and sunitinib, 4 (Figure 1) an inhibitor of VEGFR-1, VEGFR-2, fms-like tyrosine kinase-3 (Flt-3), PDGFR, stem cell factor receptor (c-Kit) and colony stimulating factor receptor (cFMS) have been approved for renal cell carcinoma. ${ }^{21,} 22$ These two RTK inhibitors are in clinical evaluation alone and in combination with other agents against a variety of cancers. However, multiple RTK inhibitors are in some instances more prone to yield side effects than selective RTK inhibitors. $24^{-} 26$ Protein kinases share very similar structural features, which are often responsible for cross-reactivities in various kinases, producing the undesirable side efects. ${ }^{24}$ For example, the approved multiple RTK inhibitors sorafenib and sunitinib have been reported to be cardiotoxic. ${ }^{25,26}$ Thus, specific inhibitors of VEGFR-2 or other RTKs would also be of considerable interest. 
Gangjee et al. ${ }^{27}$ previously reported compounds 5-7 (Figure 2) as multiple RTK inhibitors in a series of $N^{4}$-(3-bromophenyl)-6-phenylmethylsubstituted-7H-pyrrolo[2,3- $d$ ]pyrimidine-2,4diamines. Compound 5 was a potent VEGFR-2 inhibitor and demonstrated A431 cytotoxicity and moderate EGFR inhibition in the cellular assays. ${ }^{27}$ Compound $\mathbf{6}$ was a potent VEGFR-2 inhibitor and a moderate PDGFR $\beta$ and VEGFR-1 inhibitor. ${ }^{27}$ In the previously reported series, the 6-(2,4-dichlorophenyl)methyl substituted compound 7, was a potent EGFR inhibitor, with poor VEGFR-2 inhibition. ${ }^{27}$ Since VEGFR-2 has been implicated as the principal mediator of angiogenesis $5{ }^{-}{ }^{-} 11$ and VEGFR-2 stimulation alone is sufficient to induce tumor growth and metastases, ${ }^{11}$ it was of interest to structurally design VEGFR-2 inhibition in the 6-(2,4dichlorophenyl)methyl pyrrolo[2,3-d]pyrimidine scaffold of compound 7, to afford either a dual EGFR/VEGFR-2 inhibitor or perhaps a selective VEGFR-2 inhibitor.

In order to design VEGFR-2 inhibitory activity into compound 7, various anilino substitutions were explored in compounds 8-15. These anilino substitutions were selected on the basis of the potent VEGFR-2 ${ }^{28-31}$ and EGFR ${ }^{32-33}$ inhibition reported for similar anilino substitutions in 6-6 fused scaffolds such as quinazolines, pthalazines and pyrido[2,3- $d$ ]pyrimidines. Small, lipophilic, electron-deficient substitutions at the ortho-position of the 4-anilino ring combined with a larger, lipophilic, electron withdrawing moiety at the para-position such as chlorine or bromine have provided potent VEGFR-2 inhibition in quinazolines. ${ }^{30,31}$ Thus, compounds $\mathbf{8}$, with the 2-chloro, 4-bromo anilino moiety and $\mathbf{9}$, with the 2-fluoro, 4-chloro aniline moiety were synthesized.

Small substitutions at the meta position of the anilino ring such as a 3-hydroxy and a 3trifluoromethyl have also been reported to afford potent VEGFR-2 and EGFR inhibition, ${ }^{28-}$ 31 while larger, electron withdrawing substitutions such as 3-bromo and 3-chloro are preferred for EGFR inhibition in bicyclic 6-6 fused scaffolds. ${ }^{32,33}$ In order to improve the potency of VEGFR-2 inhibition and perhaps provide an optimal combination for VEGFR-2 and EGFR inhibition in the target compounds, we elected to substitute the phenyl ring of the anilino moiety at the 3-position with small, lipophilic, electron withdrawing substituents such as the 3-fluoro in 10, 3-trifluoromethyl in $\mathbf{1 1}$ and 3-ethynyl in $\mathbf{1 2}$.

Disubstitution at the 2,4- and 3,4- position of the anilino derivatives have also shown good inhibitory activities against VEGFR-2, while retaining moderate EGFR inhibition.30,31 In addition, these substitutions showed a preference for VEGFR-2 and EGFR over PDGFR and other kinases has been reported (VEGFR $>$ EGFR >PDGFR, FGFR, IGF-1R). ${ }^{30,} 31$ Thus, in addition to the 2,4-disubstituted compounds $\mathbf{8}$ and $\mathbf{9}$, the 3,4-disubstituted derivative $\mathbf{1 3}$ with a 3-fluoro, 4-trifluoromethyl anilino was also synthesized.

Bulky groups at the para-position which include electron donating alkyl groups and electron withdrawing substitutions such as halogens and aryl substitutions have also been reported to be conducive for potent VEGFR-2 inhibition, ${ }^{28,29,34,35}$ thus the 4-isopropyl aniline derivative $\mathbf{1 4}$ was synthesized. Its regioisomer, $\mathbf{1 5}$ was synthesized to restrict the conformation of the anilino ring with respect to the pyrrolo[2,3- $d]$ pyrimidine scaffold and thereby determine its effect on RTK inhibition.

The 2- $\mathrm{NH}_{2}$ moiety of compound $\mathbf{7}^{27}$ was maintained in compounds $\mathbf{8}-\mathbf{1 5}$ to provide an additional hydrogen bond in the Hinge region of RTKs compared to other known RTK inhibitors that lack this 2- $\mathrm{NH}_{2}$ moiety. The flexible 6-(2,4-dichlorobenzyl) substitution was maintained to allow for multiple conformations of the sidechain and as a result, perhaps afford interactions with two or more RTKs.

Molecular modeling using SYBYL $7.0^{34}$ showed two possible modes of binding of 5 to VEGFR-2. The first or Mode 1 is shown in Figure 3. Compound $\mathbf{5}$ was energy minimized (Minimize and Search Option in SYBYL 7.0) and superimposed onto the crystal structure of 
a furo[2,3- $d$ ] pyrimidine in VEGFR-2 (PDB: 1 YWN) ${ }^{35,36}$ (Figure 3). In this model, the pyrrolo [2,3-d]pyrimidine occupies the adenine region of the ATP binding site. The N3 of the pyrimidine in $\mathbf{5}$ is hydrogen bonded to the backbone $\mathrm{NH}$ of Cys917 and the aniline $\mathrm{NH}$ is hydrogen bonded to the backbone carbonyl of Glu915. An additional hydrogen bond between the backbone carbonyl of Cys 917 and the 2- $\mathrm{NH}_{2}$ on the pyrimidine ring of $\mathbf{5}$ is not observed in ATP or the reported furo[2,3- $d$ ] pyrimidine. ${ }^{35,36}$ These hydrogen bond interactions serve to anchor the heterocyclic portion of the molecule to VEGFR-2 and appropriately orient the other parts of the molecule in the ATP binding site.

Compound 5 in Mode 1 in VEGFR-2 (PDB code: 1YWN) showing the key interactions. Hydrogen bonding in the Hinge region between the 2- $\mathrm{NH}_{2}$ and the backbone carbonyl of Cys917, N3 and NH of Cys917 and 4-anilino NH and backbone carbonyl of Glu915. Hydrophobic interactions between the 4-anilino phenyl ring and Val897 and Cys1043 are indicated. Hydrophobic interactions between the 6-benzyl ring and Val846 and carbon chain of Lys866 (shown in dotted van der Waals surface for VEGFR-2).

Compound 5 in Mode 2 in VEGFR-2 (PDB code: 1YWN) showing hydrogen bonding in the Hinge region between the 2- $\mathrm{NH}_{2}$ and the backbone carbonyl of Cys917, N3 and $\mathrm{NH}$ of Cys917 and pyrrolo $\mathrm{NH}$ and backbone carbonyl of Glu915.

An alternate mode of binding or Mode 2 (Figure 4), is obtained from Mode 1 by rotating the $\mathrm{C} 2-\mathrm{NH}_{2}$ bond by $180^{\circ}$. Mode 2 has the 4-anilino moiety binding in the Sugar pocket rather than in the Hydrophobic region as in Mode 1. In Mode 2, the 7-position pyrrolo NH mimics the anilino NH of Mode 1 and forms one of the H-bonds with the Hinge region, substituting for the 4-NH of ATP; the N1-nitrogen forms the second H-bond and mimics the N3-nitrogen of Mode 1 and ATP.

Thus, molecular modeling provided credence to our hypothesis of the possible binding modes of our target compounds 8-15 to VEGFR-2, similar to that shown for 5. An additional aspect of our work was to evaluate the role of the 2- $\mathrm{NH}_{2}$ moiety for RTK inhibition. The 2- $\mathrm{NH}_{2}$ moiety was originally incorporated in our design ${ }^{27}$ of pyrrolo[2,3- $d$ ]pyrimidines on the basis of molecular modeling as shown in Figures 3 and 4 to afford an additional hydrogen bond in the Hinge region of RTKs compared to most of the known 6-6 and 6-5 bicyclic pyrido[2,3- $d$ ] pyrimidines, quinazolines and furo[2,3- $d$ ] pyrimidines that lack the $2-\mathrm{NH}_{2}$ moiety. ${ }^{28-33,34}$

In order to specifically demonstrate that the $2-\mathrm{NH}_{2}$ moiety does indeed contribute to an increase in the potency of the 6-phenylmethylsubstituted-7H-pyrrolo[2,3- $d$ ]pyrimidin-2,4-diamines, it was necessary to synthesize pairs of analogs with and without the 2- $\mathrm{NH}_{2}$ group. Thus, $\mathrm{N}^{4}-$ phenylsubstituted-6-phenylmethylsubstituted-7 $H$-pyrrolo[2,3- $d$ ] pyrimidin-4-amines, 16-20 (Figure 5) were synthesized as the 2-des $\mathrm{NH}_{2}$ analogs of 5, 6, 7, 11 and 12 respectively.

\section{Chemistry}

The key intermediate in the synthesis of 8-15 was the 6-(2,4-dichlorophenyl)methyl-3,7dihydro-4H-pyrrolo[2,3-d] pyrimidin-4-one 23 (Scheme 1). Several methods have been published for the synthesis of 6-substituted pyrrolo[2,3-d]pyrimidines. ${ }^{27,37-43} \mathrm{We}^{27}$ previously synthesized $\mathbf{2 3}$ by utilizing the method reported by Secrist and $\mathrm{Liu}^{37}$ that involved the reaction of $\alpha$-bromomethylbenzylketones with 2,6-diamino-4-oxopyrimidine, 22. Secrist and $\mathrm{Liu}^{37}$ reported the regiospecific formation of 6-substituted pyrrolo[2,3- $\left.d\right]$ pyrimidines in the reaction of $\alpha$-bromomethylketones with $\mathbf{2 2}$ in DMF. These authors also reported a mixture of the 6-substituted-pyrrolo[2,3- $d$ ] pyrimidines and the 5-substituted-furo[2,3- $d$ ]pyrimidines by the reaction of $\alpha$-chloromethylketones with $\mathbf{2 2}$ in DMF. In subsequent reports, Gangjee et al. ${ }^{38}$ reported the reaction of 3-bromo-4-piperidone hydrobromide with $\mathbf{2 2}$ to afford only the tricyclic tetrahydropyrido annulated-2,4-diaminofuro[2,3-d]pyrimidine. Secrist and $\mathrm{Liu}^{27}$ had 
also reported the formation of furo[2,3- $d]$ pyrimidines exclusively with cyclic $\alpha$ chloromethylketones.

We repeated the reported methodology to obtain $\mathbf{2 3}$ as described previously. ${ }^{27}$ Careful scrutiny of the TLC for the reaction of $\alpha$-bromomethyl-(2,4-dichlorobenzyl)ketone, $\mathbf{2 1}$ with $\mathbf{2 2}$ revealed three spots [TLC $\left.R_{f} 0.57,0.60,0.65\left(\mathrm{CHCl}_{3} / \mathrm{CH}_{3} \mathrm{OH}, 5: 1\right)\right]$. Two of the products, 23 and 24 were separated by column chromatography, however the third product, $\mathbf{2 5}$ ( $<5 \%$ yield) could not be separated from 24. The 6-(2,4-dichlorobenzyl)-3,7-dihydro-4H-pyrrolo[2,3- $d]$ pyrimidin-4-one, $23\left(R_{f} 0.57\right)$ was the major product, isolated in $44 \%$ yield. The $R_{f}$ and the ${ }^{1} \mathrm{H}$ NMR for the minor products were distinct from the starting materials 21 and 22 and the product 23. ${ }^{1} \mathrm{H}$ NMR for one of the minor products, $\mathbf{2 4}\left(R_{f} 0.60\right)$, showed two $\mathrm{D}_{2} \mathrm{O}$ exchangeable peaks at $5.91 \mathrm{ppm}$ and $6.12 \mathrm{ppm}$ that integrated for two protons each and were assigned to the 2,4-diNH 2 of $\mathbf{2 4}$. A singlet at 5.13 ppm that integrated for one proton was assigned to the C5$\mathrm{H}$ of the pyrimidine. In addition, two singlets that integrated for two protons each at $4.85 \mathrm{ppm}$ and $4.00 \mathrm{ppm}$ and aromatic peaks at $7.37-7.58 \mathrm{ppm}$ were also observed. These proton positions and their integration along with the HRMS confirmed the structure to be the monocyclic 2,4diamino-6-substituted pyrimidine $\mathbf{2 4}$ (Scheme 2). Compound $\mathbf{2 4}$ is most likely formed by the attack of the 4-hydroxy group of $\mathbf{2 2}$ on the halogen of the $\alpha$-bromomethylbenzylketone, $\mathbf{2 1}$ and could be an intermediate in the pathway toward the 2,4-diamino-5-substituted furo[2,3- $d]$ pyrimidine, a by product isolated in previous reports. ${ }^{37}$

The above method for $\mathbf{2 3}$ involved the formation of additional side products, moderate yields, prolonged reaction times and required purification by column chromatography. We attempted an alternate method for the synthesis of 23. The regiospecific synthesis of 6-substituted pyrrolo $[2,3-d]$ pyrimidines by the reaction of $\alpha$-chloromethylbenzylketones with $\mathbf{2 2}$ in sodium acetate and water at reflux has been previously reported by Gangjee et al. ${ }^{39-42}$ and other groups. ${ }^{43}$ We attempted this method (Scheme 2) for the synthesis of 6-(2,4-dichlorophenyl)methyl-3,7dihydro-4H-pyrrolo[2,3-d]pyrimidin-4-one 23 based on the shorter reaction time (6-12 h vs $72 \mathrm{~h}$ ) and significantly improved yields for the pyrrolo[2,3- $d]$ pyrimidines, without the formation of any furo[2,3-d]pyrimidines or byproducts. ${ }^{39-43}$

The appropriate chloroketones $\mathbf{2 8}$ and $\mathbf{2 9}$ were synthesized by treating the appropriate diazoketones $\mathbf{2 6}^{27}$ and $\mathbf{2 7} 7^{27}$ with conc $\mathrm{HCl}$ at reflux (Scheme 2). The chloroketones $\mathbf{2 8}$ and $\mathbf{2 9}$ were treated with $\mathbf{2 2}, \mathrm{NaOAc}$ and water at reflux to afford $\mathbf{2 3}$ and $\mathbf{3 0}$ respectively in 65$70 \%$ yield. Chlorination of $\mathbf{2 3}$ proceeded in poor yields, hence, $\mathbf{2 3}$ was first pivaloylated at the $2-\mathrm{NH}_{2}$ moiety followed by chlorination and treatment with appropriate aniline to the target compounds 8-15 as described in Scheme 2. Prolonged reflux (16-48 h) of the 4-chloro intermediates $\mathbf{3 3}$ and $\mathbf{3 4}$ with the appropriate anilines in isopropanol and a few drops of conc $\mathrm{HCl}$ resulted in displacement of the 4-chloro with the aniline and simultaneous depivaloylation to afford the target compounds 8,9,12 and 14. Reaction with the anilines in isopropanol and 2-3 drops of conc $\mathrm{HCl}$ in the microwave reactor (Emrys Liberator microwave synthesizer, Biotage Inc.) for $45 \mathrm{~min}$ at $120^{\circ} \mathrm{C}$ afforded compounds $\mathbf{1 0}, \mathbf{1 1}$ and $\mathbf{1 3}$ respectively.

Based on the potent RTK inhibiton seen for the previously reported $\mathbf{5}$, we resynthesized $\mathbf{5}$ in larger quantities for an in vivo assay as described in Scheme 2. The 2- $\mathrm{NH}_{2}$ moiety in 30 was first pivaloylated to 32 and then chlorinated with $\mathrm{POCl}_{3}$ to afford $\mathrm{N}$-[4-chloro-6-(2methylbenzyl)-7H-pyrrolo[2,3-d]pyrimidin-2-yl]-2,2-dimethylpropanamide, 34 in $55 \%$ yield compared to the 4-chloro-6-(2-methylbenzyl)-7H-pyrrolo[2,3- $d]$ pyrimidine-2-amine ${ }^{27}$ that was previously reported in $28 \%$ yield. Nucleophilic displacement of the 4-chloro in $\mathbf{3 4}$ with 3 bromoaniline and simultaneous depivaloylation on prolonged reflux afforded $\mathbf{5}$.

The 2-des $\mathrm{NH}_{2}$ compounds 16-20 (Figure 5) were synthesized (Scheme 3), somewhat differently from 8-15. Reaction of bromoacetone with ethylamidinoacetate, $\mathbf{3 6}^{45}$ to afford the 
corresponding pyrroles, followed by cyclization with formamide to the corresponding pyrrolo $[2,3-d]$ pyrimidines, has been reported in the literature. ${ }^{44-46} \mathrm{We}$ modified this procedure for the synthesis of 16-20. The appropriate $\alpha$-bromomethylbenzylketones with $\mathbf{3 2}$ at reflux afforded the appropriately substituted pyrroles 37-39 which were heated with formamide to afford the 6-substitutedphenylmethyl-3,7-dihydro-4H-pyrrolo[2,3- $d$ ]pyrimidin-4-ones, 4042. Compounds 40-42 were chlorinated with $\mathrm{POCl}_{3}$ to $\mathbf{4 3 - 4 5}$ and subsequent treatment with the appropriate anilines, $\mathbf{3 5}$ afforded the target compounds 16-20.

\section{Biological Evaluation and Discussion}

Compounds 8-20 were evaluated as RTK inhibitors using human tumor cells known to express high levels of EGFR, VEGFR-2, VEGFR-1 and PDFGR- $\beta$ using a phosphotyrosine ELISA cytoblot (Table 1) ${ }^{47}$ Whole cell assays were used for RTK inhibitory activity since these assays afford more meaningful results for translation to in vivo studies. The effect of compounds on cell proliferation was measured using A431 cancer cells, known to overexpress EGFR. EGFR is known to play a role in the overall survival of A431 cells. ${ }^{47}$

Since the $\mathrm{IC}_{50}$ values of compounds vary under different assay conditions (eg. ATP concentrations), standard compounds (Figure 6) were used as controls in each of the evaluations. The standard compounds used were semaxanib (SU5416), 46 for VEGFR-2; 48 cisplatin, $\mathbf{4 7}$ for A431 cytoxicity, (4-chloro-2-fluorophenyl)-6,7-dimethoxyquinazolin-4-ylamine (CB676475), 48 for VEGFR-1; ${ }^{32}$ 4-[(3-bromophenyl)amino]-6,7dimethoxyquinazoline (PD153035), 49 for EGFR; ${ }^{31}$ and 3-(4-dimethylaminobenzylidenyl)-2-indolinone (DMBI), $\mathbf{5 0}$ for PDGFR- $\beta{ }^{49}$ In addition, FDA approved receptor tyrosine kinase inhibitors erlotinib, $\mathbf{1}$ and sunitinib, $\mathbf{4}$ were also incorporated for a comparison in the in vitro study against EGFR, VEGFR-2 and PDGFR- $\beta$ kinases. Sunitinib, $\mathbf{4}$ displayed two digit micromolar inhibitions of VEGFR-2 and PDGFR- $\beta$ while erlotinib displayed single digit micromolar inhibition of EGFR. The inhibitory potencies ( $\mathrm{IC}_{50}$ values) of $\mathbf{8 - 1 5}$ are compared with the previously synthesized compound $7^{27}$ (Figure 1) and the standard compounds 1, 4, 46-50 in Table 1.

\section{VEGFR-2}

Previously synthesized compound $\mathbf{7}$ did not show significant VEGFR-2 inhibition and was less potent than semaxanib in the cellular assay. Compounds 8, 10 and $\mathbf{1 4}$ of this series showed inhibition of VEGFR-2 that was more potent than the standards, semaxanib 46 and sunitinib 4. In the disubstituted anilino derivatives, compound $\mathbf{8}$ with the 2-chloro, 4-bromo anilino substitution was 100-fold more potent than semaxanib. However, the 2-fluoro, 4-chloro anilino derivative 9 and the 3-fluoro, 4-trifluoromethyl anilino derivative $\mathbf{1 3}$ did not inhibit VEGFR-2. VEGFR-2 inhibition also improved in the 3-substituted anilino derivatives, when the 3-bromo in $\mathbf{7}$ was replaced with a 3 -fluoro in $\mathbf{1 0}$. Compound $\mathbf{1 0}$ was 40 -fold better than semaxanib, 46. VEGFR-2 inhibition decreased significantly with variations to the 3-ethynyl in $\mathbf{1 2}$ and was abolished on variation to the 3-trifluoromethyl in 11. The 4-isopropyl substitution in 14, however provided potent VEGFR-2 inhibition that was 8-fold more potent than semaxanib, $\mathbf{4 6}$ while the 2-isopropyl substitution in $\mathbf{1 5}$ abrogated VEGFR-2 inhibition.

\section{EGFR}

In the 6-(2,4-dichlorophenylmethyl)substituted pyrrolo[2,3- $d$ ]pyrimidines, compound 7 was a potent EGFR inhibitor. EGFR inhibition significantly decreased or was abolished on variation of the 3-bromo anilino substitution in $\mathbf{7}$ to other anilino moieties in 8-15. Compound 9 with the 2-fluoro, 4-chloro anilino substitution was the most potent EGFR inhibitor in this series of compounds, although EGFR inhibition decreased by 10 -fold in $\mathbf{9}$ compared to 7 and the standard 49 (PD153035). 
VEGFR-1

Compounds 8-15 and the lead compound $\mathbf{7}$ were inactive against VEGFR-1. Compound $\mathbf{9}$ with the 2-fluoro, 4-chloro anilino substitution was the best and was 5-fold less active than the standard 48 (CB676475).

\section{PDGFR- $\beta$}

Compound 7 showed two-digit micromolar inhibition of PDGFR- $\beta$ and was less potent than the standard 50 (DMBI) and sunitinib, 4. Analogs 8-15 also showed diminished activity compared to $\mathbf{5 0}$ however compounds $\mathbf{9}$ and $\mathbf{1 5}$ retained two-digit micromolar inhibition as seen in the lead compound $\mathbf{7}$ and were 6.5 -fold and 11.5 -fold less potent than $\mathbf{5 0}$ respectively. Compounds 9 and 15 were approximately 2-fold and 4-fold less potent than the standard compound 4.

\section{A431 cytotoxicity}

Compound 7 showed potent inhibition in the A431 cytotoxicity assay and was more potent than the standard, cisplatin. All three disubstituted anilino compounds 8,9 and 13 showed potent A431 cytotoxicity, more potent or equipotent with cisplatin, but slightly less potent than compound 7. The $\mathrm{IC}_{50}$ value for compound 9 was 1.7 -fold less potent than the lead compound 7. The 3-ethynylsubstituted anilino derivative, $\mathbf{1 2}$ also showed single digit micromolar inhibitory activities in the A431 cytoxicity assay and was almost equipotent with cisplatin and approximately 3-fold less potent than 7 . Interestingly, compounds 8,12 and 13 showed reasonably potent A431 cytoxicities although they did not show significant EGFR inhibition. The A431 cell lines depend on EGFR for survival; perhaps these compounds do not directly inhibit EGFR but influence the downstream signaling of EGFR and crosstalk with other kinases which may be necessary for EGFR function. The literature contains several similar reports in which the EGFR inhibitory activity does not necessarily translate into A431 cytotoxicity. ${ }^{31,34}$

\section{Multiple RTK inhibition}

Compounds 8, 10 and 14 were the most potent VEGFR-2 inhibitors of this study. The improvement in VEGFR-2 inhibition for 8, 10 and $\mathbf{1 4}$ was obtained with a simultaneous decline in EGFR inhibition. Compound $\mathbf{9}$ retained moderate, dual EGFR and VEGFR-2 inhibition, and was 3.8-fold less potent than the semaxanib, $\mathbf{4 6}$ against VEGFR-2 and 10-fold less potent than the standard compound 49 (PD153035) against EGFR. Compound 9 also showed moderate VEGFR-1 inhibition and was 5-fold less potent than the standard 48 (CB676475). The 3ethynyl substitution present in $\mathbf{1 2}$ was derived from the quinazoline-derived EGFR inhibitor, erlotinib, 1. ${ }^{12,32,33}$ Compound $\mathbf{1 2}$ however, did not show EGFR inhibition. This indicates that the scaffold that holds the anilino moiety is also important for specificity of inhibition of an RTK.

Since the inhibitory activities are determined in cells, it is not possible to make a definite structure-activity relationship for compounds 8-15 and RTK inhibition. However, the cellular assays discussed above clearly indicate that variation in the phenyl substitution of the anilino moiety does indeed control the potency and specificity of RTK inhibition. Since some anilino substitutions in 8-15 do not follow RTK inhibitory profiles observed for the 6-6 fused scaffolds, the optimal substitution pattern on the anilino moiety needs to be determined individually for each of the various scaffolds showing RTK inhibition.

A comparison of the RTK inhibitory activities and A431 cytotoxicity for the 2- $\mathrm{NH}_{2}$ substituted compounds 5-7 and 14-15 with their 2-des $\mathrm{NH}_{2}$ analogs 16-20 respectively is provided in Table 2, along with the standards. 
VEGFR-2

The 2- $\mathrm{NH}_{2}$ substituted compounds $\mathbf{5}$ and $\mathbf{6}$ showed potent submicromolar inhibition of VEGFR-2. The corresponding 2-des $\mathrm{NH}_{2}$ analogs $\mathbf{1 6}$ and $\mathbf{1 7}$ were 108 -fold and $>300$-fold less potent than 5 and $\mathbf{6}$ respectively, and were 2 -fold and $>16$-fold less potent than the standard, semaxanib 46. The 2- $\mathrm{NH}_{2}$ substituted compounds 7, 11 and $\mathbf{1 2}$ did not show potent inhibition of VEGFR-2. The VEGFR-2 inhibition further decreased for the corresponding 2-des $\mathrm{NH}_{2}$ analogs 18, 19 and 20 respectively.

EGFR

The 2-des $\mathrm{NH}_{2}$ compounds 16-20 showed poor inhibitory potencies against EGFR, compared to the 2- $\mathrm{NH}_{2}$ substituted compounds $\mathbf{5 - 7}$ and $\mathbf{1 1}$ and $\mathbf{1 2}$ and the standard compound $\mathbf{4 9}$ (PD1530305).

\section{VEGFR-1}

The 2- $\mathrm{NH}_{2}$ substituted compound $\mathbf{6}$ showed moderate VEGFR-1 inhibition, approximately 2fold less potent than the standard $\mathbf{4 8}$. The corresponding 2-des $\mathrm{NH}_{2}$ analog $\mathbf{1 7}$ was $>6$-fold less potent than 6 and $>14$-fold less potent than the standard 48. VEGFR-1 inhibition did not improve for the 2-des $\mathrm{NH}_{2}$ analogs 16, 18, 19 and 20 compared to the 2- $\mathrm{NH}_{2}$ substituted compounds 5, 7, 11 and 12 respectively and also compared to the standard, 48 (CB676475).

\section{PDGFR- $\beta$}

The PDGFR- $\beta$ inhibition did not improve for the 2-des $\mathrm{NH}_{2}$ analogs 16-20 compared to the 2- $\mathrm{NH}_{2}$ substituted compounds 5-7, 11 and 12 respectively.

\section{A431 cytotoxicity}

The 2- $\mathrm{NH}_{2}$ substituted compounds $\mathbf{5 , 7}$ and $\mathbf{1 2}$ showed potent A431 cytotoxicity being more potent or equipotent to the standard, cisplatin. The A431 cytotoxicity significantly decreased for the corresponding 2-des $\mathrm{NH}_{2}$ analogs 16, 18 and 20 compared to 5, 7 and 12 respectively, and compared to cisplatin. The A431 cytotoxicity improved for the 2-des $\mathrm{NH}_{2}$ analog $\mathbf{1 7}$ compared to $\mathbf{6}$ and cisplatin, 47.

A consistent decrease in RTK inhibition in whole cells was observed for the 2-des $\mathrm{NH}_{2}$ compounds, 16-20, with the exception of the potent inhibition seen in the A431 cytotoxicity assay for 17. The study of the 2- $\mathrm{NH}_{2}$ substituted compounds and their corresponding 2-des $\mathrm{NH}_{2}$ analogs confirms our original hypothesis that a $2-\mathrm{NH}_{2}$ should provide additional hydrogen bonding interactions that translates into improved inhibition for RTK and A431 cytotoxicity for the 2- $\mathrm{NH}_{2}$ substituted compounds compared to their 2-des $\mathrm{NH}_{2}$ analogs.

\section{In vivo evaluation}

Two compounds, compound $\mathbf{8}$ of this study and previously synthesized analog $\mathbf{5}$ were selected on the basis of their cellular RTK inhibitory activities for in vivo evaluation of inhibition of tumor growth, vascularity and metastasis. The compounds were evaluated in a B16-F10 murine metastatic melanoma model. This model is widely accepted for evaluating tumor growth and metastases, with highly vascularized tumors so that tumor-mediated angiogenesis can also be evaluated. Compound $\mathbf{5}$ showed potent VEGFR-2 inhibition, A431 cytotoxicity and moderate EGFR inhibition in the cellular assays, while $\mathbf{8}$ showed potent VEGFR-2 inhibition and A431 cytotoxicity. Compounds $\mathbf{5}$ and $\mathbf{8}$ were dosed intraperitoneally, three times weekly at $35 \mathrm{mg} /$ kg. SU6668, $\mathbf{5 1}^{21}$ (Figure 6), an analog of the approved drug sunitinib and a potent inhibitor of c-Kit, VEGFR-2, PDGFR- $\beta$ and fibroblast derived growth factor receptor-1 (FGFR-1) was used as a standard in this study and was dosed three times weekly at $10 \mathrm{mg} / \mathrm{kg}$. 
The results of the inhibitory activity of compounds $\mathbf{5 , 8}$ and $\mathbf{5 1}$ on primary tumor growth are shown in Figure 7. Compounds $\mathbf{5}$ and $\mathbf{8}$ showed an inhibition in tumor growth compared to the untreated (sham) animals. Both $\mathbf{5}$ and $\mathbf{8}$ were effective antitumor agents compared to untreated animals, however they were somewhat less effective than $\mathbf{5 1}$.

The effect of compounds $\mathbf{5 , 8}$ and $\mathbf{5 1}$ on primary tumor vascularity is shown in Figure 8. All three agents $(\mathbf{5}, \mathbf{8}$ and $\mathbf{5 1})$ induced a significant decrease in tumor vascularity compared to tumors from untreated (sham) animals. Compounds 5 and $\mathbf{8}$ were both somewhat more effective than $\mathbf{5 1}$ in the inhibition of tumor vascularity.

The effect of compounds $\mathbf{5 , 8}$ and $\mathbf{5 1}$ on tumor metastasis is shown in Figure 9. The F10 variant of the B16-F10 tumor was selected for lung metastasis and one month after implantation, $90 \%$ of the animals showed lung metastases. These studies revealed that lung metastasis was inhibited with all three compounds $\mathbf{5 , 8}$ and $\mathbf{5 1}$ compared with the untreated (sham) animals. Compound $\mathbf{5}$ was more effective than $\mathbf{5 1}$ in the inhibition of lung metastasis. Compound $\mathbf{8}$ also showed some inhibition of lung metastasis compared to the untreated animals but was less effective than either $\mathbf{5}$ or $\mathbf{5 1}$.

The in vivo antitumor evaluation of $\mathbf{5}$ and $\mathbf{8}$ suggest that both compounds cause an inhibition in tumor growth, angiogenesis and metastasis. Compound $\mathbf{5}$ shows a better inhibition of tumor angiogenesis and metastasis compared to $\mathbf{8}$. Compound $\mathbf{8}$ shows significant inhibition of angiogenesis but is less effective in inhibition of tumor metastasis.

\section{Summary}

In summary, compounds 8-15 were synthesized to improve the VEGFR-2 inhibition by variation of the phenyl substitutions of the 4 -anilino moiety in compound 7 . Three compounds $\mathbf{8 , 1 0}$ and 14 showed potent cellular VEGFR-2 inhibitions and were much more potent or equipotent to the standard compound semaxanib. In fact, compounds 8,10 and 14 were selective VEGFR-2 inhibitors and were devoid of any inhibitory activity against the other RTKs evaluated. Two compounds, $\mathbf{9}$ and $\mathbf{1 2}$ showed potent cytotoxic effects against A431 cells in culture, equipotent or more potent than the standard.

The cellular inhibition assays demonstrated that the potency and selectivity of the inhibition of different RTKs varies with different anilino substitutions, and that a combination of the substitutions in the 4-anilino ring and the 6-benzyl substituent dictates both specificity and potency of RTK inhibition in the 6-benzyl substituted pyrrolo[2,3- $d$ ] pyrimidines. The different RTK inhibitory profiles observed for compounds 8-15 in this study suggest that individual substituent optimization of the anilino moiety will be necessary for each of the various scaffolds for different RTK inhibitions.

The lack of inhibitory activity of the 2-des $\mathrm{NH}_{2}$ analogs, 16-20 supports our design strategy of incorporating a 2- $\mathrm{NH}_{2}$ moiety in the 6-benzyl substituted pyrrolo[2,3- $d$ ] pyrimidines for improved potency of RTK inhibition by providing an additional hydrogen bond with the Hinge region of RTKs. The in vivo antitumor activities of $\mathbf{5}$ and $\mathbf{8}$ indicate that both compounds cause an inhibition in tumor growth, angiogenesis and metastasis. Compound $\mathbf{5}$ was more effective in the inhibition of tumor angiogenesis and metastasis than the standard 51. Compound $\mathbf{8}$ was also more effective in the inhibition of tumor angiogenesis than the standard 51, but less effective than both $\mathbf{5}$ and $\mathbf{5 1}$ in the inhibition of tumor growth and metastasis. The demonstrated VEGFR-2 selectivity of $\mathbf{8}$ provides antiangiogenic activity in vivo as predicted. The in vivo antitumor activity of $\mathbf{5}$ and $\mathbf{8}$ indicates that whole cell RTK inhibitory activity does translate into successful in vivo activity and warrants the further development of $\mathbf{5}$ and $\mathbf{8}$ as antitumor agents. 


\section{Experimental}

\section{Synthesis}

Analytical samples were dried in vacuo $(0.2 \mathrm{mmHg})$ in a CHEMDRY drying apparatus over $\mathrm{P}_{2} \mathrm{O}_{5}$ at $80{ }^{\circ} \mathrm{C}$. Melting points were determined on a MEL-TEMP II melting point apparatus with FLUKE $51 \mathrm{~K} / \mathrm{J}$ electronic thermometer and are uncorrected. Nuclear magnetic resonance spectra for proton $\left({ }^{1} \mathrm{H}\right.$ NMR) were recorded on a Bruker WH-300 $(300 \mathrm{MHz})$ or a Bruker 400 MHz/52 MM (400 MHz) spectrometer. The chemical shift values are expressed in ppm (parts per million) relative to tetramethylsilane as an internal standard: s, singlet; $d$, doublet; $t$, triplet; q, quartet; m, multiplet; br, broad singlet. Mass spectra were recorded on a VG-7070 doublefocusing mass spectrometer or in a LKB-9000 instrument in the electron ionization (EI) or electron spray (ESI) mode. Chemical names follow IUPAC nomenclature. Thin-layer chromatography (TLC) was performed on Whatman Sil G/UV254 silica gel plates with a fluorescent indicator, and the spots were visualized under 254 and $366 \mathrm{~nm}$ illumination. Proportions of solvents used for TLC are by volume. Column chromatography was performed on a $230-400$ mesh silica gel (Fisher, Somerville, NJ) column. Elemental analyses were performed by Atlantic Microlab, Inc., Norcross, GA. Element compositions are within $0.4 \%$ of the calculated values. Fractional moles of water or organic solvents frequently found in some analytical samples could not be prevented in spite of $24-48 \mathrm{~h}$ of drying in vacuo and were confirmed where possible by their presence in the 1H NMR spectra. Microwave-assisted synthesis was performed utilizing an Emrys Liberator microwave synthesizer (Biotage) utilizing capped reaction vials. All microwave reactions were performed with temperature control. All solvents and chemicals were purchased from Aldrich Chemical Co. or Fisher Scientific and were used as received.

\section{2-Amino-6-(2,4-dichlorobenzyl)-3,7-dihydro-4H-pyrrolo[2,3-d]pyrimidin-4-one (23)}

To a $250 \mathrm{~mL}$ round-bottom flask was added a solution of $\mathbf{2 6}(2.3 \mathrm{~g}, 10 \mathrm{mmol})$ in diethylether $(50 \mathrm{~mL})$. Aqueous $\mathrm{HCl}(15 \mathrm{~mL})$ was added dropwise and the yellow mixture was refluxed for $1 \mathrm{~h}$. The reaction mixture was cooled and the ether layer was separated, washed with water (50 $\mathrm{mL}$ ) and dried over $\mathrm{Na}_{2} \mathrm{SO}_{4}$. The organic layer was evaporated to afford $2 \mathrm{~g}(84 \%)$ of $\mathbf{2 8}$ as a yellow solid. To a $250 \mathrm{~mL}$ round-bottom flask was added 22 (1 eq), NaOAc (1.3 eq) and water $(180 \mathrm{~mL})$. The reaction mixture was refluxed for $20 \mathrm{~min}$, and then a solution of $\mathbf{2 8}(2 \mathrm{~g}, 8.4$ $\mathrm{mmol})$ in $\mathrm{MeOH}(2 \mathrm{~mL})$ was added. The reaction mixture was refluxed for another $12 \mathrm{~h}$. The reaction mixture was cooled to $0{ }^{\circ} \mathrm{C}$ and filtered. The solid collected was washed with $\mathrm{MeOH}$ and diethyl ether to afford $1.96 \mathrm{~g}(75 \%)$ of $\mathbf{2 3}$; $\mathrm{mp} 265^{\circ} \mathrm{C}$ (lit. $\mathrm{mp} 265^{\circ} \mathrm{C}$ ). ${ }^{27}$ The compound was identical in all respects to the mp, $R_{f},{ }^{1} \mathrm{H}$ NMR as that reported. ${ }^{27}$

\section{2-Amino-6-(2-methylbenzyl)-3,7-dihydro-4H-pyrrolo[2,3- $d]$ pyrimidin-4-one (30)}

Compound $\mathbf{3 0}$ was synthesized as described for $\mathbf{2 3}$ with $\mathbf{2 7}$ and was obtained as an off white solid (65\%); mp $290{ }^{\circ} \mathrm{C}$ (lit. mp $290{ }^{\circ} \mathrm{C}$ )..$^{27}$ The compound was identical in all respects to the $\mathrm{mp}, R_{f},{ }^{1} \mathrm{H}$ NMR as that reported. ${ }^{27}$

\section{1-(2,6-Diamino-pyrimidin-4-yloxy)-3-(2,4-dichlorophenyl)-propan-2-one (24)}

To a $250 \mathrm{~mL}$ round-bottom flask was added $\mathbf{1 7 ^ { 2 7 }}$ (2 g, $\left.7.1 \mathrm{mmol}\right)$, 2,6-diaminopyrimidin-4one and dry DMF $(10 \mathrm{~mL})$. The mixture was stirred at room temperature for 3 days. The reaction mixture was dried in vacuo and the residue was purified by flash chromatography on silica gel (gradient, $1-5 \% \mathrm{MeOH}$ in $\mathrm{CHCl}_{3}$ ) to afford $970 \mathrm{mg}(44 \%)$ of $\mathbf{2 3}$ as a yellow solid (mp, $R_{f},{ }^{1} \mathrm{H}$ NMR as that reported) ${ }^{27}$ and $23 \mathrm{mg}(10 \%)$ of $\mathbf{2 4}$ as an off-white solid; TLC $R_{f} 0.60$ $\left(\mathrm{CHCl}_{3}: \mathrm{CH}_{3} \mathrm{OH}, 5: 1\right) ; \mathrm{mp} 152-153{ }^{\circ} \mathrm{C} ;{ }^{1} \mathrm{H}$ NMR (DMSO- $\left.d_{6}\right) \delta 4.01$ (s, $2 \mathrm{H}, \mathrm{CH}_{2}$ ), 4.85 (s, 2 $\left.\mathrm{H}, \mathrm{CH}_{2}\right), 5.12(\mathrm{~s}, 1 \mathrm{H}, \mathrm{CH}), 5.92\left(\mathrm{~s}, 2 \mathrm{H}, \mathrm{NH}_{2}\right), 6.12\left(\mathrm{~s}, 2 \mathrm{H}, \mathrm{NH}_{2}\right), 7.35-7.60(\mathrm{~m}, 3 \mathrm{H}$, $\mathrm{C}_{6} \mathrm{H}_{3}$ ). HRMS (EI): Calcd for $\mathrm{C}_{13} \mathrm{H}_{12} \mathrm{~N}_{4} \mathrm{O}_{2} \mathrm{Cl}_{2} \mathrm{~m} / \mathrm{z}=326.0337$, found $\mathrm{m} / \mathrm{z}=326.0337$. 


\section{N-[4-Chloro-6-(2,4-dichlorobenzyl)-7H-pyrrolo[2,3-d]pyrimidin-2-yl]-2,2- dimethylpropanamide (33)}

To a $50 \mathrm{~mL}$ round-bottom flask, under nitrogen, was added compound $\mathbf{2 3}(800 \mathrm{mg}, 2.59 \mathrm{mmol})$ and excess $\mathrm{Piv}_{2} \mathrm{O}(4 \mathrm{eq})$. The mixture was stirred at $100-120^{\circ} \mathrm{C}$ for $2 \mathrm{~h}$. The reaction mixture was cooled and hexane $(40 \mathrm{~mL})$ was added. The suspension was filtered to afford $850 \mathrm{mg}$ (85\%) of 31 as a light brown solid; TLC $R_{f} 0.56\left(\mathrm{CHCl}_{3} / \mathrm{MeOH}, 10: 1\right)$. To a $100-\mathrm{mL}$ roundbottom flask was added $\mathbf{3 1}(300 \mathrm{mg}, 1.3 \mathrm{mmol})$ and $\mathrm{POCl}_{3}(12 \mathrm{~mL})$. The mixture was refluxed for $3 \mathrm{~h}$. The reaction mixture was evaporated and quenched with water $(15 \mathrm{~mL})$. The resulting solution was cooled in an ice bath, and the $\mathrm{pH}$ was adjusted to 8-9 with dropwise addition of $\mathrm{NH}_{4} \mathrm{OH}$. The mixture was diluted with $\mathrm{CHCl}_{3}(120 \mathrm{~mL})$. The organic layer was separated and dried over $\mathrm{Na}_{2} \mathrm{SO}_{4}$, filtered, and concentrated under reduced pressure to afford a yellow solid. The crude product was purified by flash chromatography on silica gel (isocratic, $\mathrm{CHCl}_{3}$ ) to afford $180 \mathrm{mg}(58 \%)$ of $\mathbf{3 3}$ as a yellow fluffy solid; TLC $R_{f} 0.81\left(\mathrm{CHCl}_{3} / \mathrm{MeOH}, 10: 1\right) ; \mathrm{mp}$ 122-124 ${ }^{\circ} \mathrm{C} ;{ }^{1} \mathrm{H}$ NMR (DMSO- $\left.d_{6}\right) \delta 1.21\left(\mathrm{~s}, 9 \mathrm{H}, \mathrm{C}\left(\mathrm{CH}_{3}\right)_{3}\right), 4.17\left(\mathrm{~s}, 2 \mathrm{H}, \mathrm{CH}_{2}\right), 6.07(\mathrm{~s}, 1 \mathrm{H}$, $\mathrm{CH}), 7.39-7.84\left(\mathrm{~m}, 3 \mathrm{H}, \mathrm{C}_{6} \mathrm{H}_{3}\right), 10.01(\mathrm{~s}, 1 \mathrm{H}, \mathrm{NH}), 12.40$ (s, $\left.1 \mathrm{H}, \mathrm{NH}\right)$. HRMS (ESI) [M + $\mathrm{Na}]^{+}$calcd for $\mathrm{C}_{19} \mathrm{H}_{21} \mathrm{~N}_{4} \mathrm{Cl}_{3} \mathrm{~m} / z=433.0729$, found $\mathrm{m} / z=433.0744$.

\section{N-[4-Chloro-6-(2-methylbenzyl)-7H-pyrrolo[2,3-d]pyrimidin-2-yl]-2,2-dimethylpropanamide (34) \\ Compound $\mathbf{3 4}$ was synthesized as described for $\mathbf{3 3}$ with $\mathbf{3 0}$ and was obtained as a yellow fluffy solid (55\%); $R_{f}=0.76\left(\mathrm{CHCl}_{3} / \mathrm{MeOH} 10: 1\right) ; \mathrm{mp} 117-119{ }^{\circ} \mathrm{C} ;{ }^{1} \mathrm{H}$ NMR (DMSO-d $\left.d_{6}\right) \delta 1.22$ (s, 9H, $\left.\mathrm{C}\left(\mathrm{CH}_{3}\right)_{3}\right), 2.27\left(\mathrm{~s}, 3 \mathrm{H}, \mathrm{CH}_{3}\right), 4.05\left(\mathrm{~s}, 2 \mathrm{H}, \mathrm{CH}_{2}\right), 6.07$ (s, $\left.1 \mathrm{H}, \mathrm{CH}\right), 7.15-7.19(\mathrm{~m}, 4$ $\left.\mathrm{H}, \mathrm{C}_{6} \mathrm{H}_{4}\right), 9.99$ (s, $\left.1 \mathrm{H}, \mathrm{NH}\right), 12.36(\mathrm{~s}, 1 \mathrm{H}, \mathrm{NH})$. HRMS (ESI) $[\mathrm{M}+\mathrm{H}]^{+}$calcd for $\mathrm{C}_{19} \mathrm{H}_{22} \mathrm{~N}_{4} \mathrm{OCl} \mathrm{m} / z=357.1482$, found $m / z=357.1470$.}

\section{$N^{4}$-(2-Bromo-4-chlorophenyl)-6-(2,4-dichlorobenzyl)-7 H-pyrrolo[2,3- $\left.d\right]$ pyrimidine-2,4- diamine (8)}

To a $100 \mathrm{~mL}$ round-bottom flask was added $\mathbf{3 3}$ ( $200 \mathrm{mg}, 0.48 \mathrm{mmol}$ ), 2-bromo-4-chloroaniline $(1.5 \mathrm{eq}), i \mathrm{PrOH}(20 \mathrm{~mL})$ and 6 drops of conc $\mathrm{HCl}$. The mixture was refluxed for $12 \mathrm{~h}$. After being cooled, the reaction mixture was dried in vacuo. The residue was neutralized with $\mathrm{NH}_{4} \mathrm{OH}(1 \mathrm{~mL})$ and extracted with $\mathrm{CHCl}_{3}(30 \mathrm{~mL})$. The organic layer was dried over $\mathrm{Na}_{2} \mathrm{SO}_{4}$, filtered, and concentrated under reduced pressure to afford a yellow solid. The crude product was purified by flash chromatography on silica gel (gradient, $\mathrm{CHCl}_{3}$ to $2 \% \mathrm{MeOH} /$ $\mathrm{CHCl}_{3}$ ) and washed with diethyl ether to afford $180 \mathrm{mg}(74 \%)$ of $\mathbf{8}$ as a white solid; TLC $R_{f}$ $0.58\left(\mathrm{CHCl}_{3} / \mathrm{CH}_{3} \mathrm{OH}, 10: 1\right) ; \mathrm{mp} 203{ }^{\circ} \mathrm{C} ;{ }^{1} \mathrm{H}$ NMR (DMSO-d 6 ) $\delta 3.99\left(\mathrm{~s}, 2 \mathrm{H}, \mathrm{CH}_{2}\right), 5.60(\mathrm{~s}$, $\left.2 \mathrm{H}, \mathrm{NH}_{2}\right), 5.91(\mathrm{~s}, 1 \mathrm{H}, \mathrm{CH}), 7.36-7.72\left(\mathrm{~m}, 6 \mathrm{H}, \mathrm{C}_{6} \mathrm{H}_{3}\right.$ and $\left.\mathrm{C}_{6} \mathrm{H}_{3}\right), 8.45(\mathrm{~s}, 1 \mathrm{H}, \mathrm{NH}), 10.91$ (s, $1 \mathrm{H}, \mathrm{NH})$. Anal. $\left(\mathrm{C}_{19} \mathrm{H}_{13} \mathrm{Cl}_{3} \mathrm{BrN}_{5} \bullet 0.35 \mathrm{H}_{2} \mathrm{O}\right) \mathrm{C}, \mathrm{H}, \mathrm{N}, \mathrm{Br}, \mathrm{Cl}$.

\section{$N^{4}$-(2-Fluoro-4-chlorophenyl)-6-(2,4-dichlorobenzyl)-7H-pyrrolo[2,3-d]pyrimidine-2,4- diamine (9)}

Compound 9 was synthesized as described for $\mathbf{8}$ with 4-chloro-2-fluoroaniline and was obtained as a light yellow solid (86\%); TLC $R_{f} 0.57\left(\mathrm{CHCl}_{3} / \mathrm{CH}_{3} \mathrm{OH}, 10: 1\right) ; \mathrm{mp} 214{ }^{\circ} \mathrm{C} ;{ }^{1} \mathrm{H}$ NMR (DMSO- $\left.d_{6}\right) \delta 4.00\left(\mathrm{~s}, 2 \mathrm{H}, \mathrm{CH}_{2}\right), 5.62\left(\mathrm{~s}, 2 \mathrm{H}, \mathrm{NH}_{2}\right), 5.99(\mathrm{~s}, 1 \mathrm{H}, \mathrm{CH}), 7.19-7.90(\mathrm{~m}$, $6 \mathrm{H}, \mathrm{C}_{6} \mathrm{H}_{3}$ and $\left.\mathrm{C}_{6} \mathrm{H}_{3}\right), 8.95(\mathrm{~s}, 1 \mathrm{H}, \mathrm{NH}), 10.92(\mathrm{~s}, 1 \mathrm{H}, \mathrm{NH})$. Anal. $\left(\mathrm{C}_{19} \mathrm{H}_{13} \mathrm{Cl}_{3} \mathrm{FN}_{5} \bullet 0.3 \mathrm{H}_{2} \mathrm{O}\right)$ $\mathrm{C}, \mathrm{H}, \mathrm{N}, \mathrm{F}, \mathrm{Cl}$.

\section{$N^{4}$-(3-Ethynylphenyl)-6-(2,4-dichlorobenzyl)-7H-pyrrolo[2,3- $d$ ]pyrimidine-2,4-diamine (12)}

Compound $\mathbf{1 2}$ was synthesized as described for $\mathbf{8}$ with 3-ethynylaniline and was obtained as a yellow solid (52 mg, 53\%); TLC $R_{f} 0.55\left(\mathrm{CHCl}_{3} / \mathrm{CH}_{3} \mathrm{OH}, 10: 1\right)$; mp $219^{\circ} \mathrm{C} ;{ }^{1} \mathrm{H}$ NMR (DMSO$\left.d_{6}\right) \delta 4.01\left(\mathrm{~s}, 2 \mathrm{H}, \mathrm{CH}_{2}\right), 4.1(\mathrm{~s}, 1 \mathrm{H}, \mathrm{CH}), 5.72\left(\mathrm{~s}, 2 \mathrm{H}, \mathrm{NH}_{2}\right), 6.04(\mathrm{~s}, 1 \mathrm{H}, \mathrm{CH}), 6.90-8.06(\mathrm{~m}$, 
$7 \mathrm{H}, \mathrm{C}_{6} \mathrm{H}_{4}$ and $\left.\mathrm{C}_{6} \mathrm{H}_{3}\right), 8.81(\mathrm{~s}, 1 \mathrm{H}, \mathrm{NH}), 10.92(\mathrm{~s}, 1 \mathrm{H}, \mathrm{NH})$. Anal. $\left(\mathrm{C}_{21} \mathrm{H}_{15} \mathrm{Cl}_{2} \mathrm{~N}_{5} \bullet 0.21 \mathrm{H}_{2} \mathrm{O}\right)$ $\mathrm{C}, \mathrm{H}, \mathrm{N}, \mathrm{Cl}$.

$\boldsymbol{N}^{4}$-(4-Isopropylphenyl)-6-(2,4-dichlorobenzyl)-7H-pyrrolo[2,3-d]pyrimidine-2,4-diamine (14)

Compound $\mathbf{1 4}$ was synthesized as described for $\mathbf{8}$ with 4-isopropylaniline and was obtained as an off-white solid (122 mg, 63\%); mp $218{ }^{\circ} \mathrm{C}$; TLC $R_{f} 0.54\left(\mathrm{CHCl}_{3} / \mathrm{CH}_{3} \mathrm{OH}, 10: 1\right) ;{ }^{1} \mathrm{H}$ NMR $\left(\mathrm{DMSO}_{6} d_{6}\right) 1.19\left(\mathrm{~d}, 6 \mathrm{H}, \mathrm{CH}_{3}, J=6 \mathrm{~Hz}\right), 2.8(\mathrm{~m}, 1 \mathrm{H}, \mathrm{CH}, J=6 \mathrm{~Hz}), 4.00\left(\mathrm{~s}, 2 \mathrm{H}, \mathrm{CH}_{2}\right)$, $5.63\left(\mathrm{~s}, 2 \mathrm{H}, \mathrm{NH}_{2}\right), 6.02(\mathrm{~s}, 1 \mathrm{H}, \mathrm{CH}), 7.09\left(\mathrm{~d}, 2 \mathrm{H}, \mathrm{C}_{6} \mathrm{H}_{4}, J=9 \mathrm{~Hz}\right), 7.77\left(\mathrm{~d}, 2 \mathrm{H}, \mathrm{C}_{6} \mathrm{H}_{4}, J=9\right.$ $\mathrm{Hz}), 7.37-7.64\left(\mathrm{~m}, 3 \mathrm{H}, \mathrm{C}_{6} \mathrm{H}_{3}\right), 8.69(\mathrm{~s}, 1 \mathrm{H}, \mathrm{NH}), 10.86(\mathrm{~s}, 1 \mathrm{H}, \mathrm{NH})$. Anal. $\left(\mathrm{C}_{22} \mathrm{H}_{21} \mathrm{Cl}_{2} \mathrm{~N}_{5}\right) \mathrm{C}$, $\mathrm{H}, \mathrm{N}, \mathrm{Cl}$.

$\boldsymbol{N}^{\mathbf{4}}$-(2-Isopropylphenyl)-6-(2,4-dichlorobenzyl)-7H-pyrrolo[2,3-d]pyrimidine-2,4-diamine (15)

Compound $\mathbf{1 5}$ was synthesized as described for $\mathbf{8}$ with 2-isopropylaniline and was obtained as a white solid (102 mg, 72\%); TLC $R_{f} 0.54\left(\mathrm{CHCl}_{3} / \mathrm{CH}_{3} \mathrm{OH}, 10: 1\right) ; \mathrm{mp} 216{ }^{\circ} \mathrm{C} ;{ }^{1} \mathrm{H}$ NMR $\left(\right.$ DMSO- $\left.d_{6}\right) \delta 1.09\left(\mathrm{~d}, 6 \mathrm{H}, \mathrm{CH}_{3}, J=6 \mathrm{~Hz}\right), 3.17(\mathrm{~m}, 1 \mathrm{H}, \mathrm{CH}, J=6 \mathrm{~Hz}), 3.90\left(\mathrm{~s}, 2 \mathrm{H}, \mathrm{CH}_{2}\right)$, $5.40\left(\mathrm{~s}, 2 \mathrm{H}, \mathrm{NH}_{2}\right), 5.44(\mathrm{~s}, 1 \mathrm{H}, \mathrm{CH}), 7.15-7.59\left(\mathrm{~m}, 7 \mathrm{H}, \mathrm{C}_{6} \mathrm{H}_{4}\right.$ and $\left.\mathrm{C}_{6} \mathrm{H}_{3}\right), 8.33(\mathrm{~s}, 1 \mathrm{H}, \mathrm{NH})$, 10.74 (s, $1 \mathrm{H}, \mathrm{NH})$. Anal. $\left(\mathrm{C}_{22} \mathrm{H}_{21} \mathrm{Cl}_{2} \mathrm{~N}_{5} \bullet 0.05 \mathrm{CHCl}_{3}\right) \mathrm{C}, \mathrm{H}, \mathrm{N}, \mathrm{Cl}$.

\section{$N^{4}$-(3-Bromophenyl)-6-(2-methylbenzyl)-7 H-pyrrolo[2,3- $\left.d\right]$ pyrimidine-2,4-diamine (5)}

Compound 5 was synthesized as described for $\mathbf{8}$ with $\mathbf{3 4}$ and 3-bromoaniline and was obtained as an off white solid ( $315 \mathrm{mg}, 70 \%$ ); $\mathrm{mp} 226^{\circ} \mathrm{C}$ (lit. mp 225-228 ${ }^{\circ} \mathrm{C}$ ). ${ }^{27}$ The compound was identical in all respects to the mp, $R_{f},{ }^{1} \mathrm{H}$ NMR as that reported. ${ }^{27}$ Anal. $\left(\mathrm{C}_{20} \mathrm{H}_{18} \mathrm{BrN}_{5} \bullet 0.04\right.$ $\left.\mathrm{CHCl}_{3}\right) \mathrm{C}, \mathrm{H}, \mathrm{N}, \mathrm{Br}$.

\section{$N^{4}$-(3-Fluorophenyl)-6-(2,4-dichlorobenzyl)-7 H-pyrrolo[2,3- $\left.d\right]$ pyrimidine-2,4-diamine (10)}

To a 2-5 mL microwave reaction vial was added $\mathbf{3 3}$ (300 $\mathrm{mg}, 0.73 \mathrm{mmol})$, 3-fluoroaniline (1.5 eq), $i$-PrOH $(4 \mathrm{~mL}), \mathrm{DMF}(1 \mathrm{~mL})$ and 4 drops of conc $\mathrm{HCl}$. The reaction mixture was irradiated in a microwave apparatus at $120^{\circ} \mathrm{C}$ for $45 \mathrm{~min}$. After being cooled, the reaction mixture was dried in vacuo. The residue was neutralized with $\mathrm{NH}_{4} \mathrm{OH}(1 \mathrm{~mL})$ and extracted with $\mathrm{CHCl}_{3}$ $(40 \mathrm{~mL})$. The organic layer was dried over $\mathrm{Na}_{2} \mathrm{SO}_{4}$, filtered, and concentrated under reduced pressure to afford a yellow solid. The crude product was purified by flash chromatography on silica gel (gradient, $\mathrm{CHCl}_{3}$ to $2 \% \mathrm{MeOH} / \mathrm{CHCl}_{3}$ ) and washed with diethyl ether to afford 180 $\mathrm{mg}(61 \%)$ of 6 as a light yellow solid; TLC $R_{f} 0.56\left(\mathrm{CHCl}_{3} / \mathrm{CH}_{3} \mathrm{OH}, 10: 1\right) ; \mathrm{mp} 221{ }^{\circ} \mathrm{C} ;{ }^{1} \mathrm{H}$ NMR (DMSO- $\left.d_{6}\right) \delta 4.01\left(\mathrm{~s}, 2 \mathrm{H}, \mathrm{CH}_{2}\right), 5.82\left(\mathrm{~s}, 2 \mathrm{H}, \mathrm{NH}_{2}\right), 6.05(\mathrm{~s}, 1 \mathrm{H}, \mathrm{CH}), 6.69-8.08(\mathrm{~m}$, $7 \mathrm{H}, \mathrm{C}_{6} \mathrm{H}_{4}$ and $\left.\mathrm{C}_{6} \mathrm{H}_{3}\right), 8.94(\mathrm{~s}, 1 \mathrm{H}, \mathrm{NH}), 10.96(\mathrm{~s}, 1 \mathrm{H}, \mathrm{NH})$. Anal. $\left(\mathrm{C}_{19} \mathrm{H}_{14} \mathrm{Cl}_{2} \mathrm{FN}_{5} \bullet 0.11\right.$ $\left.\mathrm{CHCl}_{3}\right) \mathrm{C}, \mathrm{H}, \mathrm{N}, \mathrm{F}, \mathrm{Cl}$.

\section{$N^{4}$-(3-Trifluoromethylphenyl)-6-(2,4-dichlorobenzyl)-7H-pyrrolo[2,3-d]pyrimidine-2,4- diamine (11)}

Compound $\mathbf{1 1}$ was synthesized as described for $\mathbf{1 0}$ with 3-trifluoromethylaniline and was obtained as an off white solid (65\%); TLC $R_{f} 0.56\left(\mathrm{CHCl}_{3} / \mathrm{CH}_{3} \mathrm{OH}, 10: 1\right) ; \mathrm{mp} 216{ }^{\circ} \mathrm{C} ;{ }^{1} \mathrm{H}$ NMR (DMSO- $\left.d_{6}\right) \delta 4.02\left(\mathrm{~s}, 2 \mathrm{H}, \mathrm{CH}_{2}\right), 6.04(\mathrm{~s}, 1 \mathrm{H}, \mathrm{CH}), 5.78\left(\mathrm{~s}, 2 \mathrm{H}, \mathrm{NH}_{2}\right), 6.69(\mathrm{t}, 1 \mathrm{H}$, $\left.\mathrm{C}_{6} \mathrm{H}_{4}\right), 7.20-8.46\left(\mathrm{~m}, 7 \mathrm{H}, \mathrm{C}_{6} \mathrm{H}_{4}\right.$ and $\left.\mathrm{C}_{6} \mathrm{H}_{3}\right), 9.07(\mathrm{~s}, 1 \mathrm{H}, \mathrm{NH}), 11.00(\mathrm{~s}, 1 \mathrm{H}, \mathrm{NH})$. Anal. $\left(\mathrm{C}_{20} \mathrm{H}_{14} \mathrm{Cl}_{2} \mathrm{~F}_{3} \mathrm{~N}_{5} \bullet 0.03 \mathrm{CHCl}_{3}\right) \mathrm{C}, \mathrm{H}, \mathrm{N}, \mathrm{F}, \mathrm{Cl}$.

\section{$N^{4}$-(3-Fluoro-4-trifluoromethylphenyl)-6-(2,4-dichlorobenzyl)-7H-pyrrolo[2,3-d] pyrimidine-2,4-diamine (13)}

Compound 13 was synthesized as described for 10 with 3-fluoro-4-trifluoromethylaniline and was obtained as an off white solid (57\%); TLC $R_{f} 0.58\left(\mathrm{CHCl}_{3} / \mathrm{CH}_{3} \mathrm{OH}, 10: 1\right) ; \mathrm{mp} 220-222^{\circ}$ $\mathrm{C} ;{ }^{1} \mathrm{H}$ NMR (DMSO- $\left.d_{6}\right) \delta 4.00\left(\mathrm{~s}, 2 \mathrm{H}, \mathrm{CH}_{2}\right), 6.01$ (s, $\left.1 \mathrm{H}, \mathrm{C} 5-\mathrm{H}\right), 5.79\left(\mathrm{~s}, 2 \mathrm{H}, \mathrm{NH}_{2}\right.$ ), 7.26- 
8.19 (m, $6 \mathrm{H}, \mathrm{Ar}-\mathrm{H}), 8.91(\mathrm{~s}, 1 \mathrm{H}, \mathrm{NH}), 10.97$ (s, $1 \mathrm{H}, \mathrm{NH})$. Anal. $\left(\mathrm{C}_{20} \mathrm{H}_{13} \mathrm{Cl}_{2} \mathrm{~F}_{4} \mathrm{~N}_{5} \bullet 0.44\right.$ $\left.\mathrm{CH}_{3} \mathrm{OH}\right) \mathrm{C}, \mathrm{H}, \mathrm{N}, \mathrm{F}, \mathrm{Cl}$.

\section{Ethyl-2-amino-5-(2-methylbenzyl)-1H-pyrrole-3-carboxylate (37)}

To a $250 \mathrm{~mL}$ round-bottom flask, under nitrogen was added carbethoxyacetamidine hydrochloride $36,{ }^{44} \mathrm{NEt}_{3}(20 \mathrm{~mL})$ and ethyl acetate $(40 \mathrm{~mL})$. The reaction mixture was stirred for at room temperature for $20 \mathrm{~min}$, and then $\alpha$-bromomethyl-(2-methylbenzyl)ketone ( $2 \mathrm{~g}, 9$ $\mathrm{mmol}),{ }^{27}$ was added and the mixture was refluxed for $1 \mathrm{~h}$. After being cooled, the reaction mixture was dried in vacuo. The crude product was purified by flash chromatography on silica gel (gradient, $10-50 \%$. EtOAc/hexane) to afford $1.3 \mathrm{~g} \mathrm{(60 \% )}$ of $\mathbf{3 7}$ as a red semisolid that degraded on storage and was directly used in the next step; TLC $R_{f} 0.46$ (EtOAc/hexane, 1:4); ${ }^{1} \mathrm{H}$ NMR (DMSO- $\left.d_{6}\right) \delta 1.17\left(\mathrm{t}, 3 \mathrm{H}, \mathrm{CH}_{3}, J=6 \mathrm{~Hz}\right), 2.23\left(\mathrm{~s}, 3 \mathrm{H}, \mathrm{CH}_{3}\right), 3.65(\mathrm{~s}, 2 \mathrm{H}$, $\left.\mathrm{CH}_{2}\right), 4.01\left(\mathrm{q}, 2 \mathrm{H}, \mathrm{CH}_{2}, J=6 \mathrm{~Hz}\right), 5.48\left(\mathrm{~s}, 2 \mathrm{H}, \mathrm{NH}_{2}\right), 7.11-7.13\left(\mathrm{~m}, 4 \mathrm{H}, \mathrm{C}_{6} \mathrm{H}_{4}\right), 9.96(\mathrm{~s}, 1$ $\mathrm{H}, \mathrm{NH})$.

\section{Ethyl-2-amino-5-(2,4-dichlorobenzyl)-1 H-pyrrole-3-carboxylate (38)}

Compound $\mathbf{3 8}$ was synthesized as described for $\mathbf{3 7}$ with $\alpha$-bromomethyl-(2,4-dichlorobenzyl) ketone and was obtained as an orange semisolid $(70 \%)$ that degraded on storage and was directly used in the next step; TLC $R_{f} 0.5$ (Hexane/ethylacetate, 1:4); ${ }^{1} \mathrm{H}$ NMR (DMSO- $d_{6}$ ) $\delta$ $1.20\left(\mathrm{t}, 3 \mathrm{H}, \mathrm{CH}_{3}\right), 3.49(\mathrm{~s}, 1 \mathrm{H}, \mathrm{C} 5-\mathrm{H}), 4.02\left(\mathrm{~s}, 2 \mathrm{H}, \mathrm{CH}_{2}\right), 4.23\left(\mathrm{q}, 2 \mathrm{H}, \mathrm{CH}_{2}\right), 5.59(\mathrm{~s}, 2 \mathrm{H}$, $\left.\mathrm{NH}_{2}\right), 7.24-7.58\left(\mathrm{~m}, 3 \mathrm{H}, \mathrm{C}_{6} \mathrm{H}_{4}\right), 10.08(\mathrm{~s}, 1 \mathrm{H}, \mathrm{NH})$.

\section{Ethyl-2-amino-(2,5-dimethoxybenzyl)-1 $H$-pyrrole-3-carboxylate (39)}

Compound 39 was synthesized as described for 37 with $\alpha$-bromomethyl(2,5-dimethoxybenzyl) ketone and was obtained as a red semisolid (45\%) that degraded on storage and was directly used in the next step; TLC $R_{f} 0.40$ (EtOAc/hexane, $\left.1: 4\right) ;{ }^{1} \mathrm{H}$ NMR (DMSO- $d_{6}$ ) $\delta 1.16$ (t, $3 \mathrm{H}$, $\left.\mathrm{CH}_{3}\right), 3.67$ (s, $\left.3 \mathrm{H}, \mathrm{OCH}_{3}\right), 3.79$ (s, $\left.3 \mathrm{H}, \mathrm{OCH}_{3}\right), 3.95\left(\mathrm{~s}, 2 \mathrm{H}, \mathrm{CH}_{2}\right), 4.20$ (q, $\left.2 \mathrm{H}, \mathrm{CH}_{2}\right), 5.75$ (s, $\left.2 \mathrm{H}, \mathrm{NH}_{2}\right), 6.73-6.88\left(\mathrm{~m}, 3 \mathrm{H}, \mathrm{C}_{6} \mathrm{H}_{3}\right), 9.98(\mathrm{~s}, 1 \mathrm{H}, \mathrm{NH})$.

\section{6-(2-Methylbenzyl)-3,7-dihydro-4H-pyrrolo[2,3-d]pyrimidin-4-one (40)}

To a $250 \mathrm{~mL}$ round-bottom flask, under nitrogen was added $\mathbf{3 7}$ ( $1.3 \mathrm{~g}, 5.4 \mathrm{mmol}), \mathrm{NaOMe}(0.3$ $\mathrm{g}, 50 \mathrm{mmol})$, and formamide $(100 \mathrm{~mL})$. The reaction mixture was heated to $160{ }^{\circ} \mathrm{C}$ for $12 \mathrm{~h}$. The reaction mixture was cooled and the product was precipitated with ice. The precipitate was collected by filtration and dried in vacuo to afford $0.54 \mathrm{~g}(45 \%)$ of $\mathbf{4 0}$ as a pale brown solid; TLC $R_{f} 0.55\left(\mathrm{CHCl}_{3} / \mathrm{MeOH}, 5: 1\right) ;{ }^{1} \mathrm{H}$ NMR (DMSO-d 6 ) 2.26 (s, $3 \mathrm{H}, \mathrm{CH}_{3}$ ), 3.92 (s, 2 $\left.\mathrm{H}, \mathrm{CH}_{2}\right), 5.95(\mathrm{~s}, 1 \mathrm{H}, \mathrm{CH}), 7.12-7.15\left(\mathrm{~m}, 4 \mathrm{H}, \mathrm{C}_{6} \mathrm{H}_{4}\right), 7.76(\mathrm{~s}, 1 \mathrm{H}, \mathrm{CH}), 11.71(\mathrm{~s}, 1 \mathrm{H}, \mathrm{NH})$, $11.80(\mathrm{~s}, 1 \mathrm{H}, \mathrm{NH})$.

\section{6-(2,5-Dimethoxybenzyl)-3,7-dihydro-4H-pyrrolo[2,3-d]pyrimidin-4-one (41)}

Compound $\mathbf{4 1}$ was synthesized as described for $\mathbf{4 0}$ with $\mathbf{3 9}$ and was obtained as a brown solid (40\%); TLC $R_{f} 0.51\left(\mathrm{CHCl}_{3} / \mathrm{MeOH}, 5: 1\right) ; \mathrm{mp} 220{ }^{\circ} \mathrm{C} ;{ }^{1} \mathrm{H}$ NMR (DMSO- $\left.d_{6}\right) \delta 3.67$ (s, $3 \mathrm{H}$, $\left.\mathrm{OCH}_{3}\right), 3.74\left(\mathrm{~s}, 3 \mathrm{H}, \mathrm{OCH}_{3}\right), 3.86\left(\mathrm{~s}, 2 \mathrm{H}, \mathrm{CH}_{2}\right), 6.02(\mathrm{~s}, 1 \mathrm{H}, \mathrm{CH}), 6.71-6.92(\mathrm{~m}, 3 \mathrm{H}$, $\left.\mathrm{C}_{6} \mathrm{H}_{3}\right), 7.76(\mathrm{~s}, 1 \mathrm{H}, \mathrm{CH}), 11.71(\mathrm{~s}, 1 \mathrm{H}, \mathrm{NH}), 11.75(\mathrm{~s}, 1 \mathrm{H}, \mathrm{NH})$. HRMS (ESI) $[\mathrm{M}+\mathrm{Na}]^{+}$: Calcd for $\mathrm{C}_{15} \mathrm{H}_{15} \mathrm{~N}_{3} \mathrm{O}_{3} \mathrm{Na} m / z=308.1011$, found $\mathrm{m} / \mathrm{z}=308.1013$.

\section{N-4-Chloro-6-(2,5-dimethoxybenzyl)-3,7-dihydro-4H-pyrrolo[2,3-d]pyrimidine (44)}

To a 100-mL round-bottom flask was added $41(200 \mathrm{mg}, 0.7 \mathrm{mmol})$ and $\mathrm{POCl}_{3}(12 \mathrm{~mL})$. The mixture was refluxed for $3 \mathrm{~h}$. The reaction mixture was evaporated and quenched with water $(15 \mathrm{~mL})$. The resulting solution was cooled in an ice bath, and the $\mathrm{pH}$ was adjusted to $8-9$ with dropwise addition of $\mathrm{NH}_{4} \mathrm{OH}$. The mixture was diluted with $\mathrm{CHCl}_{3}(120 \mathrm{~mL})$. The organic 
layer was separated and dried over $\mathrm{Na}_{2} \mathrm{SO}_{4}$, filtered, and concentrated under reduced pressure to afford $150 \mathrm{mg}$ ( $71 \%)$ of $\mathbf{4 4}$ as a white solid; TLC $R_{f} 0.61\left(\mathrm{CHCl}_{3} / \mathrm{MeOH}, 10: 1\right)$; mp 172$176{ }^{\circ} \mathrm{C} ;{ }^{1} \mathrm{H}$ NMR (DMSO- $\left.d_{6}\right) \delta 3.70\left(\mathrm{~s}, 3 \mathrm{H}, \mathrm{OCH}_{3}\right), 3.76\left(\mathrm{~s}, 3 \mathrm{H}, \mathrm{OCH}_{3}\right), 4.05(\mathrm{~s}, 2 \mathrm{H}$, $\mathrm{CH}_{2}$ ), 6.12 (s, $\left.1 \mathrm{H}, \mathrm{CH}\right), 6.82-6.83\left(\mathrm{~m}, 3 \mathrm{H}, \mathrm{C}_{6} \mathrm{H}_{3}\right), 8.52$ (s, $\left.1 \mathrm{H}, \mathrm{CH}\right), 12.53(\mathrm{~s}, 1 \mathrm{H}, \mathrm{NH})$.

\section{N-4-Chloro-6-(2,4-dichlorobenzyl)-3,7-dihydro-4H-pyrrolo[2,3-d]pyrimidine (45)}

To a $250 \mathrm{~mL}$ round-bottom flask, under nitrogen was added $\mathbf{3 8}(1.0 \mathrm{~g}, 5 \mathrm{mmol}), \mathrm{NaOMe}(0.3$ $\mathrm{g}, 50 \mathrm{mmol})$, and formamide $(100 \mathrm{~mL})$. The reaction mixture was heated to $160{ }^{\circ} \mathrm{C}$ for $12 \mathrm{~h}$.

The reaction mixture was cooled and $\mathbf{4 1}$ was precipitated with ice. Compound $\mathbf{4 1}$ was collected by filtration and directly used for the synthesis of $\mathbf{4 5}$. To a $100-\mathrm{mL}$ round-bottom flask was added $41(200 \mathrm{mg}, 0.7 \mathrm{mmol})$ and $\mathrm{POCl}_{3}(12 \mathrm{~mL})$. The mixture was refluxed for $3 \mathrm{~h}$. The reaction mixture was evaporated and quenched with water $(15 \mathrm{~mL})$. The resulting solution was cooled in an ice bath, and the $\mathrm{pH}$ was adjusted to 8-9 with dropwise addition of $\mathrm{NH}_{4} \mathrm{OH}$. The mixture was diluted with $\mathrm{CHCl}_{3}(120 \mathrm{~mL})$. The organic layer was separated and dried over $\mathrm{Na}_{2} \mathrm{SO}_{4}$, filtered, and concentrated under reduced pressure to afford compound $\mathbf{4 5}$ as a white solid (76\%); TLC $R_{f} 0.65\left(\mathrm{CHCl}_{3} / \mathrm{MeOH}, 10: 1\right) ;{ }^{1} \mathrm{H}$ NMR (DMSO- $\left.d_{6}\right) 4.23$ (s, $2 \mathrm{H}, \mathrm{CH}_{2}$ ), 6.13 (s, $1 \mathrm{H}, \mathrm{CH}), 7.39-7.65\left(\mathrm{~m}, 3 \mathrm{H}, \mathrm{C}_{6} \mathrm{H}_{3}\right), 8.5$ (s, $\left.1 \mathrm{H}, \mathrm{CH}\right), 12.6$ (s, $\left.1 \mathrm{H}, \mathrm{NH}\right)$. Anal. $\left(\mathrm{C}_{13} \mathrm{H}_{8} \mathrm{Cl}_{3} \mathrm{~N}_{3}\right) \mathrm{C}, \mathrm{H}, \mathrm{N}, \mathrm{Cl}$.

\section{N-4-(3-Bromophenyl)-6-(2-methylbenzyl)-3,7-dihydro-4H-pyrrolo[2,3- $d]$ pyrimidin-4-amine (16)}

To a 100-mL round-bottom flask was added $40(200 \mathrm{mg}, 0.7 \mathrm{mmol})$ and $\mathrm{POCl}_{3}(12 \mathrm{~mL})$. The mixture was refluxed for $3 \mathrm{~h}$. The reaction mixture was evaporated and quenched with water $(15 \mathrm{~mL})$. The resulting solution was cooled in an ice bath, and the $\mathrm{pH}$ was adjusted to $8-9$ with dropwise addition of $\mathrm{NH}_{4} \mathrm{OH}$. The mixture was diluted with $\mathrm{CHCl}_{3}(120 \mathrm{~mL})$. The organic layer was separated and dried over $\mathrm{Na}_{2} \mathrm{SO}_{4}$, filtered, and concentrated under reduced pressure to afford $133 \mathrm{mg}$ of $\mathbf{4 3}$ as a residue that was treated with 3-bromoaniline (1.5 eq), $i \mathrm{PrOH}$ (20 $\mathrm{mL}$ ) and 2-3 drops of conc $\mathrm{HCl}$. The mixture was refluxed for $4 \mathrm{~h}$. After being cooled, the reaction mixture was dried in vacuo. The residue was neutralized with $\mathrm{NH}_{4} \mathrm{OH}(1 \mathrm{~mL})$ and extracted with $\mathrm{CHCl}_{3}(30 \mathrm{~mL})$. The organic layer was dried over $\mathrm{Na}_{2} \mathrm{SO}_{4}$, filtered, and dried in vacuo to afford 16 as a yellow solid. The crude product was purified by flash chromatography on silica gel (gradient, $\mathrm{CHCl}_{3}$ to $2 \% \mathrm{MeOH} / \mathrm{CHCl}_{3}$ ) and washed with diethyl ether to afford $170 \mathrm{mg}(84 \%)$ of 16 as a white solid; TLC $R_{f} 0.56\left(\mathrm{CHCl}_{3} / \mathrm{CH}_{3} \mathrm{OH}, 10: 1\right) ; \mathrm{mp} 242-244^{\circ}$ $\mathrm{C} ;{ }^{1} \mathrm{H}$ NMR (DMSO- $\left.d_{6}\right): \delta 2.26\left(\mathrm{~s}, 3 \mathrm{H}, \mathrm{CH}_{3}\right), 4.03\left(\mathrm{~s}, 2 \mathrm{H}, \mathrm{CH}_{2}\right), 6.24(\mathrm{~s}, 1 \mathrm{H}, \mathrm{CH}), 7.11-$ $7.79\left(\mathrm{~m}, 8 \mathrm{H}, \mathrm{C}_{6} \mathrm{H}_{4}\right.$ and $\left.\mathrm{C}_{6} \mathrm{H}_{4}\right), 8.26(\mathrm{~s}, 1 \mathrm{H}, \mathrm{CH}), 9.29(\mathrm{~s}, 1 \mathrm{H}, \mathrm{NH}), 11.85(\mathrm{~s}, 1 \mathrm{H}, \mathrm{NH})$. Anal. $\left(\mathrm{C}_{20} \mathrm{H}_{17} \mathrm{BrN}_{4} \bullet 0.17 \mathrm{H}_{2} \mathrm{O}\right) \mathrm{C}, \mathrm{H}, \mathrm{N}, \mathrm{Br}$.

\section{N-4-(3-Bromophenyl)-6-(2,5-dimethoxybenzyl)-3,7-dihydro-4H-pyrrolo[2,3-d]pyrimidin-4- amine (17)}

To a 100-mL round-bottom flask was added 44, 3-bromoaniline (1.5 eq), $i \mathrm{PrOH}(20 \mathrm{~mL})$ and 2-3 drops of conc $\mathrm{HCl}$. The mixture was refluxed for $4 \mathrm{~h}$. After being cooled, the reaction mixture was dried in vacuo. The residue was neutralized with $\mathrm{NH}_{4} \mathrm{OH}(1 \mathrm{~mL})$ and extracted with $\mathrm{CHCl}_{3}(30 \mathrm{~mL})$. The organic layer was dried over $\mathrm{Na}_{2} \mathrm{SO}_{4}$, filtered, and dried in vacuo to afford 17 as a white solid (55\%); TLC $R_{f} 0.54\left(\mathrm{CHCl}_{3} / \mathrm{CH}_{3} \mathrm{OH}, 10: 1\right) ; \mathrm{mp} 208-210{ }^{\circ} \mathrm{C} ;{ }^{1} \mathrm{H}$ NMR (DMSO- $\left.d_{6}\right) \delta 3.67\left(\mathrm{~s}, 3 \mathrm{H}, \mathrm{OCH}_{3}\right), 3.72\left(\mathrm{~s}, 3 \mathrm{H}, \mathrm{OCH}_{3}\right), 3.96\left(\mathrm{~s}, 2 \mathrm{H}, \mathrm{CH}_{2}\right), 6.29(\mathrm{~s}, 1$ $\mathrm{H}, \mathrm{CH}), 6.80-7.81\left(\mathrm{~m}, 7 \mathrm{H}, \mathrm{C}_{6} \mathrm{H}_{4}\right.$ and $\left.\mathrm{C}_{6} \mathrm{H}_{3}\right), 8.26(\mathrm{~s}, 1 \mathrm{H}, \mathrm{CH}), 9.28(\mathrm{~s}, 1 \mathrm{H}, \mathrm{NH}), 11.79(\mathrm{~s}, 1$ $\mathrm{H}, \mathrm{NH})$. Anal. $\left(\mathrm{C}_{21} \mathrm{H}_{19} \mathrm{BrN}_{4} \mathrm{O}_{2}\right) \mathrm{C}, \mathrm{H}, \mathrm{N}, \mathrm{Br}$. 
N-4-(3-Bromophenyl)-6-(2,4-dichlorobenzyl)-3,7-dihydro-4H-pyrrolo[2,3-d]pyrimidin-4amine (18)

Compound 18 was synthesized as described for $\mathbf{1 7}$ with $\mathbf{4 5}$ and was obtained as a white solid (77\%); TLC $R_{f} 0.61\left(\mathrm{CHCl}_{3} / \mathrm{CH}_{3} \mathrm{OH}, 10: 1\right) ; \mathrm{mp} 264-265{ }^{\circ} \mathrm{C} ;{ }^{1} \mathrm{H}$ NMR (DMSO- $\left.d_{6}\right) \delta 4.15$ (s, $\left.2 \mathrm{H}, \mathrm{CH}_{2}\right), 6.27(\mathrm{~s}, 1 \mathrm{H}, \mathrm{CH}), 7.15-7.67\left(\mathrm{~m}, 7 \mathrm{H}, \mathrm{C}_{6} \mathrm{H}_{4}\right.$ and $\left.\mathrm{C}_{6} \mathrm{H}_{3}\right), 8.29(\mathrm{~s}, 1 \mathrm{H}, \mathrm{CH}), 9.29$ (s, $1 \mathrm{H}, \mathrm{NH}), 11.92$ (s, $1 \mathrm{H}, \mathrm{NH})$. Anal. $\left(\mathrm{C}_{19} \mathrm{H}_{13} \mathrm{BrCl}_{2} \mathrm{~N}_{4}\right) \mathrm{C}, \mathrm{H}, \mathrm{N}, \mathrm{Br}$.

\section{N-4-(3-Ethynylphenyl)-6-(2,4-dichlorobenzyl)-3,7-dihydro-4H-pyrrolo[2,3-d]pyrimidin-4- amine (19)}

Compound 19 was synthesized as described for $\mathbf{1 7}$ with $\mathbf{4 5}$ and 3-ethynylaniline and was obtained as a a yellow solid (65\%); TLC $R_{f} 0.57\left(\mathrm{CHCl}_{3} / \mathrm{CH}_{3} \mathrm{OH}, 10: 1\right) ; \mathrm{mp} 243-245{ }^{\circ} \mathrm{C} ;{ }^{1} \mathrm{H}$ NMR (DMSO- $\left.d_{6}\right) \delta 4.11\left(\mathrm{~s}, 2 \mathrm{H}, \mathrm{CH}_{2}\right), 4.11(\mathrm{~s}, 1 \mathrm{H}, \mathrm{CH}), 6.29(\mathrm{~s}, 1 \mathrm{H}, \mathrm{CH}), 7.06-8.10(\mathrm{~m}, 7$ $\mathrm{H}, \mathrm{C}_{6} \mathrm{H}_{4}$ and $\left.\mathrm{C}_{6} \mathrm{H}_{3}\right), 8.28$ (s, $\left.1 \mathrm{H}, \mathrm{CH}\right), 9.28(\mathrm{~s}, 1 \mathrm{H}, \mathrm{NH}), 11.89$ (s, $\left.1 \mathrm{H}, \mathrm{NH}\right)$. Anal. $\left(\mathrm{C}_{21} \mathrm{H}_{14} \mathrm{Cl}_{2} \mathrm{~N}_{4}\right) \mathrm{C}, \mathrm{H}, \mathrm{N}, \mathrm{Cl}$.

\section{N-4-(3-Trifluoromethylphenyl)-6-(2,4-dichlorobenzyl)-3,7-dihydro-4H-pyrrolo[2,3-d] pyrimidin-4-amine (20)}

Compound $\mathbf{2 0}$ was synthesized as described for $\mathbf{1 7}$ with $\mathbf{4 5}$ and 3-trifluoromethylaniline and was obtained as a white solid (77\%); TLC $R_{f} 0.58\left(\mathrm{CHCl}_{3} / \mathrm{CH}_{3} \mathrm{OH}, 10: 1\right) ; \mathrm{mp} 244-246^{\circ}$ $\mathrm{C} ;{ }^{1} \mathrm{H}$ NMR (DMSO- $\left.d_{6}\right) \delta 4.18\left(\mathrm{~s}, 2 \mathrm{H}, \mathrm{CH}_{2}\right), 6.28(\mathrm{~s}, 1 \mathrm{H}, \mathrm{CH}), 7.28-8.17\left(\mathrm{~m}, 7 \mathrm{H}, \mathrm{C}_{6} \mathrm{H}_{4}\right.$ and $\left.\mathrm{C}_{6} \mathrm{H}_{3}\right), 8.30$ (s, $\left.1 \mathrm{H}, \mathrm{CH}\right), 9.44$ (s, $\left.1 \mathrm{H}, \mathrm{NH}\right), 11.92$ (s, $\left.1 \mathrm{H}, \mathrm{NH}\right)$. Anal. $\left(\mathrm{C}_{20} \mathrm{H}_{13} \mathrm{Cl}_{2} \mathrm{~F}_{3} \mathrm{~N}_{4} \bullet 0.3\right.$ $\left.\mathrm{H}_{2} \mathrm{O}\right) \mathrm{C}, \mathrm{H}, \mathrm{N}, \mathrm{F}, \mathrm{Cl}$.

\section{Biological Evaluation}

All cells were maintained at $37{ }^{\circ} \mathrm{C}$ in a humidified environment containing $5 \% \mathrm{CO}_{2}$ using media from Mediatech (Hemden, NJ, USA). The A-431 cells were from the American Type Tissue Collection (Manassas, VA, USA). All growth factors (bFGF, VEGF, EGF, PDGF-BB) were purchased from Peprotech (Rocky Hill, NJ, USA). The PY-HRP antibody was from BD Transduction Laboratories (Franklin Lakes, NJ, USA). Antibodies against EGFR, PDGFR $\beta$, FGFR-1, Flk-1, and Flt-1 were purchased from Upstate Biotech (Framingham, MA, USA). The CYQUANT cell proliferation assay was from Molecular Probes (Eugene, OR, USA). The standard compounds used for comparison in the assays were purchased from Calbiochem (San Diego, CA, USA).

\section{Inhibition of Cellular Tyrosine Phosphorylation}

Inhibition of EGF, VEGF and PDGF-BB-stimulated total cellular tyrosine phosphorylation in tumor cells naturally expressing high levels of EGFR (A431), VEGFR-2 (U251), VEGFR-1 (A498) and PDGFR- $\beta$ (SF-539) respectively, were measured using the ELISA assay as previously reported. ${ }^{38}$ Briefly, cells at $60-75 \%$ confluence were placed in serum-free medium for $18 \mathrm{~h}$ to reduce the background of phosphorylation. Cells were always $>98 \%$ viable by Trypan blue exclusion. Cells were then pre-treated for 60 min with 333, 100, 33.3, 10, 3.33, $1.00,0.33$ and $0.10 \mu \mathrm{M}$ compound followed by $100 \mathrm{ng} / \mathrm{mL}$ EGF, VEGF, PDGF-BB, or bFGF for $10 \mathrm{~min}$. The reaction was stopped and cells permeabilized by quickly removing the media from the cells and adding ice-cold Tris-buffered saline (TBS) containing $0.05 \%$ triton X-100, protease inhibitor cocktail and tyrosine phosphatase inhibitor cocktail. The TBS solution was then removed and cells fixed to the plate by $30 \mathrm{~min}$ at $60{ }^{\circ} \mathrm{C}$ and further incubated in $70 \%$ ethanol for an additional 30 minutes. Cells were further exposed to block (TBS with $1 \%$ BSA) for $1 \mathrm{~h}$, washed, and then a horseradish peroxidase (HRP)-conjugated phosphotyrosine antibody was added overnight. The antibody was removed, cells were washed again in TBS, exposed to an enhanced luminol ELISA substrate (Pierce Chemical, Rockford, IL, USA) and 
light emission measured using an UV Products (Upland, CA, USA) BioChemi digital darkroom. Standard compounds were used as controls in each of the evaluations. The standard compounds used were semaxanib, 46 for VEGFR-2; (4-chloro-2-fluorophenyl)-6,7-dimethoxy quinazolin-4-yl-amine, $\mathbf{4 8}$ for VEGFR-1; 4-[(3-bromophenyl)amino]-6,7-

dimethoxyquinazoline, 49 for EGFR; 3-(4-dimethylamino-benzylidenyl)-2-indolinone, $\mathbf{5 0}$ for PDGFR- $\beta$. Erlotinib, $\mathbf{1}$ and sunitinib, $\mathbf{4}$ were also evaluated against VEGFR-2, EGFR and PDGFR- $\beta$ in this assay. Data were graphed as a percent of cells receiving growth factor alone and $\mathrm{IC}_{50}$ values estimated from 2-3 separate experiments $(\mathrm{n}=8-24)$ using non-linear regression Sigmoidal Dose-Response analysis with GraphPad Prism (San Diego, CA). In every case, the activity of a positive control inhibitor did not deviate more than $10 \%$ from the $\mathrm{IC}_{50}$ values listed in the text.

\section{Antiproliferative assay}

The assay was performed as described previously. ${ }^{47}$ Briefly, cells were first treated with compounds for $12 \mathrm{~h}$ and then allowed to grow for an additional $36 \mathrm{~h}$. The cells were then lysed and the CYQUANT dye, which intercalates into the DNA of cells, was added and after 5 min the fluorescence of each well measured using an UV Products BioChemi digital darkroom. Cisplatin, $\mathbf{4 7}$ was used as the standard for cytotoxicity in each experiment.. Data were graphed as a percent of cells receiving growth factor alone and $\mathrm{IC}_{50}$ values estimated from 2-3 separate experiments $(\mathrm{n}=6-15)$ using non-linear regression Sigmoidal Dose-Response analysis with GraphPad Prism (San Diego, CA).

\section{In vivo Antitumor Activity}

In vivo antitumor activity of compounds was tested at a dose of $35 \mathrm{mg} / \mathrm{kg}$ for $\mathbf{5}$ and $\mathbf{8}$, and 10 $\mathrm{mg} / \mathrm{kg}$ of standard compound $\mathbf{5 1}$ (SU6668) three times a week by intraperitoneal route against the B16-F10 (lung colonizing) melanoma implanted in athymic $\mathrm{NCr}$ nu/nu male mice. 50,000 B16-F10 mouse melanoma cells were injected orthotopically SQ just behind the ear of the mice, 8 weeks in age. Two experiments were done starting with 5-6 animals/group. Animals were monitored every other day for the presence of tumors. Drug treatment was started 9 days after tumor implantation, the time at which most tumors were measurable by calipers. DMSO stocks $(30 \mathrm{mM})$ of drugs were dissolved into sterile water for injection and $35 \mathrm{mg} / \mathrm{kg}$ was injected intraperitoneally (IP) every Monday (AM), Wednesday (noon) and Friday (PM). Sham treated animals received water only Monday, Wednesday and Friday. Values are mean \pm SEM., ${ }^{* * *}=\mathrm{P}<0.001,{ }^{* *}=\mathrm{P}<0.01$ versus untreated animals using one-way ANOVA with Neuman-Keuls post-test.

\section{Tumor growth}

The length (long side), width (short side) and depth of the tumors were measured using digital Vernier Calipers each Monday, Wednesday, and Friday. Tumor volume was calculated using the formula: length $\times$ width $\times$ depth. Tumor growth rate was calculated using a linear regression analysis algorithm using the software GraphPad Prism 4.0 as the slope of the curve from day 9 after tumor implantation, the date of first treatment, out to day 28 of the experiment. The tumor volumes at the first measurement (day 9, day of first treatment) were untreated:12.3 \pm $1.8 \mathrm{~mm}^{3}$, compound 5: $13.24 \pm 3.0 \mathrm{~mm}^{3}$, compound 8: $14.1 \pm 2.1 \mathrm{~mm}^{3}$ and $\mathbf{5 1}$ (SU6668): 11.9 $\pm 1.2 \mathrm{~mm}^{3}$.

\section{Tumor metastases and vascularity}

At the experiment's end, day 28 , the animals were humanely euthanized using carbon dioxide, tumors and lungs excised, fixed in $20 \%$ neutral buffered formalin for 8-10 hr, embedded into paraffin, and hematoxylin-eosin $(\mathrm{H} \& \mathrm{E})$ stain of three separate tissue sections completed to 
span the tumor/lung. Metastases per lung lobe were counted using the H\&E stained sections. Metastasis was seen as purple clusters of disorganized cells on the highly organized, largely pink lung. Blood vessels per unit area were counted in 5 fields at $100 \times$ magnification and averaged. Values are mean \pm SEM., ${ }^{* * *}=\mathrm{P}<0.001,{ }^{* *}=\mathrm{P}<0.01$ versus untreated animals using one-way ANOVA with Neuman-Keuls post-test.

\section{Supplementary Material}

Refer to Web version on PubMed Central for supplementary material.

\section{Acknowledgments}

This work was supported, in part, by Grant CA98850 (A.G.) from the National Cancer Institute, National Institutes of Health, and an equipment grant from the National Science Foundation (NMR: CHE 0614785).

\section{Abbreviations}

$\begin{array}{ll}\text { RTK } & \text { receptor tyrosine kinase } \\ \text { EGFR } & \text { epidermal growth factor receptor } \\ \text { PDGFR } & \text { platelet-derived growth factor receptor } \\ \text { VEGFR } & \text { vascular endothelial growth factor receptor } \\ \text { IGF-1 } & \text { insulin-like growth factor-1 } \\ \text { Flt-3 } & \text { fms-like tyrosine kinase } 3 \\ \text { c-Kit } & \text { stem cell factor receptor } \\ \text { cFMS } & \text { colony stimulating factor receptor } \\ \text { FGFR-1 } & \text { fibroblast derived growth factor receptor-1 } \\ \text { ATP } & \text { adenosine triphospate }\end{array}$

\section{References}

1. Sun L, McMahon G. Drug Discovery Today 2000;8:344. [PubMed: 10893547]

2. Shauver, L.; Lipson, K.; Fong, T.; McMahon, G.; Strawn, L. The New Angiotherapy. Fan, T.; Kohn, E., editors. Humana Press; New Jersey: 2002. p. 409-452.

3. Folkman J. Nat Rev Drug Discov 2007;6:273. [PubMed: 17396134]

4. Madhusadan S, Ganesan T. Clinical Biochemistry 2004;37:618. [PubMed: 15234243]

5. Han, L.; Lorincz, A.; Sukumar, S. Antiangiogenic Agents in Cancer Therapy. Teicher, B.; Ellis, L., editors. Vol. 2. Humana Press; New Jersey: 2008. p. 331-352.

6. Rak J, Yu J, Klement G, Kerbel R. J Invest Dermatol Symp Proc 2000;5:24.

7. Kerbel R, Folkmann J. Nat Rev Cancer 2002;2:727. [PubMed: 12360276]

8. Hubbard S. Curr Opin Struct Biol 2002;12:735. [PubMed: 12504677]

9. Ferrara N. Oncologist 2004;9:2. [PubMed: 15178810]

10. Ferrara N, Gerber H, LeCouter J. Nat Med 2003;9:669. [PubMed: 12778165]

11. Shinkaruk S, Bayle M, Lain G, Deleris G. Curr Med Chem Anti-Cancer Agents 2003;3:95.

12. Ciardiello F, Tortora G. Clin Cancer Res 2001;7:2958. [PubMed: 11595683]

13. Levitzki A. Acc Chem Res 2003;36:462. [PubMed: 12809533]

14. Lynch T, Bell D, Sordella R, Gurubhagavatula S, Okimoto R. NEngl J Med 2004;350:2129. [PubMed: 15118073]

15. Pao W, Miller V, Politi K, Riely G, Somwar R. PLoS Med 2005;2:225. 
16. Sandler A, Herbst R. Clin Cancer Res 2006;12:4421s. [PubMed: 16857821]

17. Adjei A. Clin Cancer Res 2006;12:4446s. [PubMed: 16857826]

18. Patel P, Chaganti R, Motzer R. Br J of Cancer 2006;94:614. [PubMed: 16465192]

19. De Jonge M, Verweij J. Eur J of Cancer 2006;42:1351. [PubMed: 16740386]

20. Druker J. Trends Mol Med 2002;8:S14. [PubMed: 11927282]

21. Laird A, Vajkoczy P, Shawver L, Thurnher A, Liang C, Mohammadi M, Schlessinger J, Ullrich A, Hubbard S, Blake R, Fong A, Strawn L, Sun Li, Tang Cho, Hawtin R, Tang F, Shenoy N, Hirth P, McMahon G, Cherrington J. Cancer Res 2000;60:4152. [PubMed: 10945623]

22. Wilhelm S, Carter C, Lynch M, Lowinger T, Dumas J, Smith R, Schwartz B, Simantov R, Kelley S. Nat Rev Drug Discov 2006;5:835. [PubMed: 17016424]

23. Atkins M, Jones C, Kirkpatrick P. Nat Rev Drug Discov 2006;5:279. [PubMed: 16628834]

24. Knight ZA, Shokat KM. Chem Biol 2005;12:621. [PubMed: 15975507]

25. Force T, Krause D, Van Etten R. Nat Rev Cancer 2007;7:332. [PubMed: 17457301]

26. Crespo A, Zhang X, Fernández A. J Med Chem 2008;51:4890. [PubMed: 18680272]

27. a) Gangjee A, Yang J, Ihnat M, Kamat S. Bioorg Med Chem 2003;11:5155. [PubMed: 14604679] b) Gangjee, A. US Patent No. 6,770,652. Aug 3. 2004 Multiple Acting Anti-Angiogenic and Cytotoxic Compounds and Methods for Using the Same

28. Bold G, Altmann K, Bruggen J, Frei J, Lang M, Manley PW, Traxler P, Wietfeld B, Buchdunger E, Cozens R, Ferrari S, Furet P, Hofmann F, Martiny-Baron G, Mestan J, Rosel J, Sills M, Stover D, Acemoglu F, Boss E, Emmenegger R, Lasser L, Masso E, Roth R, Schlachter C, Vetterli W, Wyss D, Wood J. J Med Chem 2000;43:2310. [PubMed: 10882357]

29. Manley P, Furet P, Bold G, Bruggen J, Mestan J, Meyer T, Schnell C, Wood J, Haberey M, Huth A, Kruger M, Menrad A, Ottow E, Seidelmann D, Siemeister G, Thierauch K. J Med Chem 2002;45:5687. [PubMed: 12477352]

30. Hennequin L, Stokes E, Thomas A, Johnstone C, Ple P, Ogilvie D, Dukes M, Wedge S, Kendrew J, Curwen J. J Med Chem 2002;45:1300. [PubMed: 11881999]

31. Hennequin L, Thomas A, Johnstone C, Stokes E, Ple P, Lohmann J, Ogilvie D, Dukes M, Wedge S, Curwen J, Kendrew J, Lambert-van der Brempt C. J Med Chem 1999;42:5369. [PubMed: 10639280]

32. Bridges A, Zhou H, Cody D, Rewcastle G, McMichael A, Showalter H, Fry D, Kraker A, Denny W. J Med Chem 1996;39:267. [PubMed: 8568816]

33. Rewcastle G, Denny W, Bridges A, Zhou H, Cody D, McMichael A, Fry D. J Med Chem 1995;38:3482. [PubMed: 7658435]

34. Tripos Inc., 1699 South Hanley Road, St. Louis, MO 63144.

35. Miyazaki Y, Matsunaga S, Tang J, Maeda Y, Nakano M, Philippe R, Shibahara M, Liu L, Sato H, Wang L, Nolte R. Bioorg Med Chem Lett 2005;15:2203. [PubMed: 15837294]

36. Harris P, Cheung M, Hunter R, Brown M, Veal J, Nolte R, Wang L, Liu W, Crosby R, Johnson J, Epperly A, Kumar R, Luttrell D, Stafford J. J Med Chem 2005;48:1610. [PubMed: 15743202]

37. Secrist J, Liu P. J Org Chem 1978;43:3937.

38. Gangjee A, Jain H, Phan J, Lin X, Song X, McGuire J, Kisliuk R. J Med Chem 2006;49:1055. [PubMed: 16451071]

39. Gangjee A, Elzein E, Kisliuk R. J Med Chem 1998;41:1409. [PubMed: 9554874]

40. Gangjee A, Mavandadi F, Kisliuk R, McGuire J, Queener S. J Med Chem 1996;39:4563. [PubMed: 8917644]

41. Gangjee A, Jain H, Queener S. J Het Chem 2005;42:589.

42. Gangjee A, Jain H, Kisliuk R. Bioorg Med Chem Lett 2005;15:2225. [PubMed: 15837298]

43. Taylor E, Young W, Chaudhari R, Patel M. Heterocycles 1993;36:1897.

44. Toja E, Tarzia G. J Het Chem 1986;23:1555.

45. Kobayashi T, Inoue T, Kita Z. Chem Pharm Bull 1995;43:788. [PubMed: 7553966]

46. Venugopalan B, Desai G, de Souza N. J Het Chem 1988;25:1633.

47. Wilson S, Barsoum M, Wilson B, Pappone P. Cell Prolif 1999;32:131. [PubMed: 10535359]

48. Arora A, Scholar E. J Pharmacol Experimental Ther 2005;315:971.

Bioorg Med Chem. Author manuscript; available in PMC 2011 May 15. 
49. Kovalenko M, Gazit A, Bohmer C, Rorsman C, Ronnstrand L, Heldin C, Waltenberger J, Bohmer F. Cancer Res 1994;54:6106. [PubMed: 7954456] 


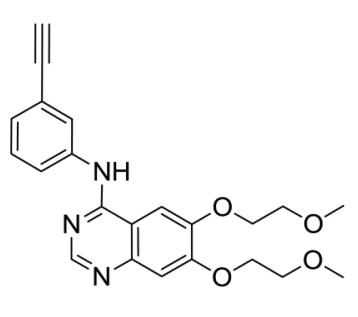

1, Erlotinib

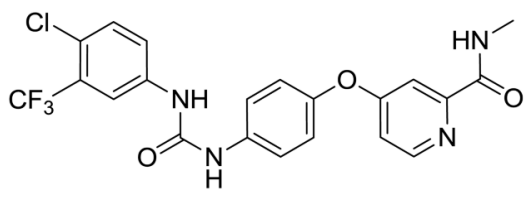

3, Sorafenib
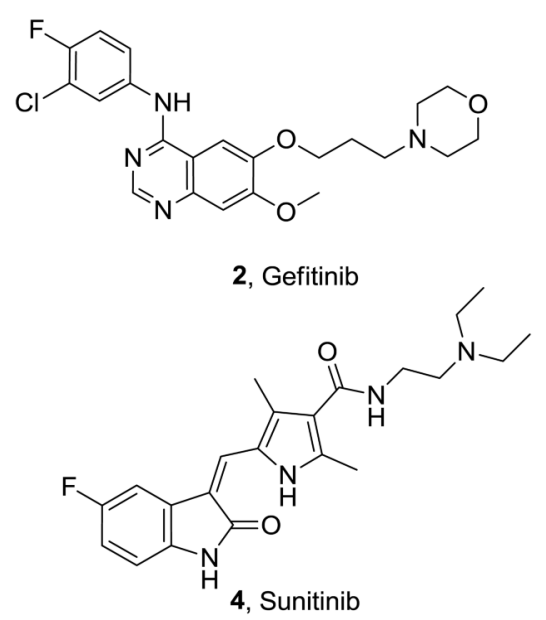

Figure 1. 

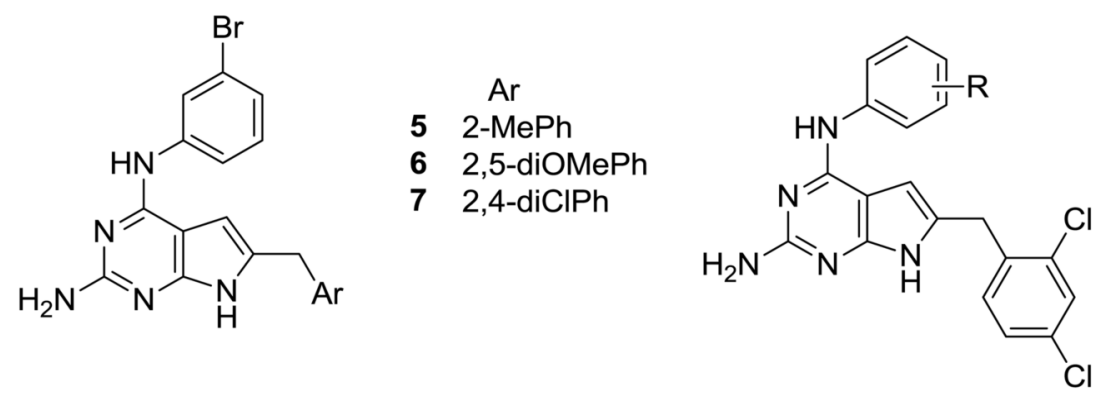

$\mathrm{R}$

8 4-Br, 2-Cl

9 4-Cl, 2-F

$103-F$

$113-\mathrm{CF}_{3}$

$123-\mathrm{C} \equiv \mathrm{CH}$

13 3-F, 4-CF 3

14 4-i $\mathrm{Pr}$

15 2-i Pr

Figure 2. 


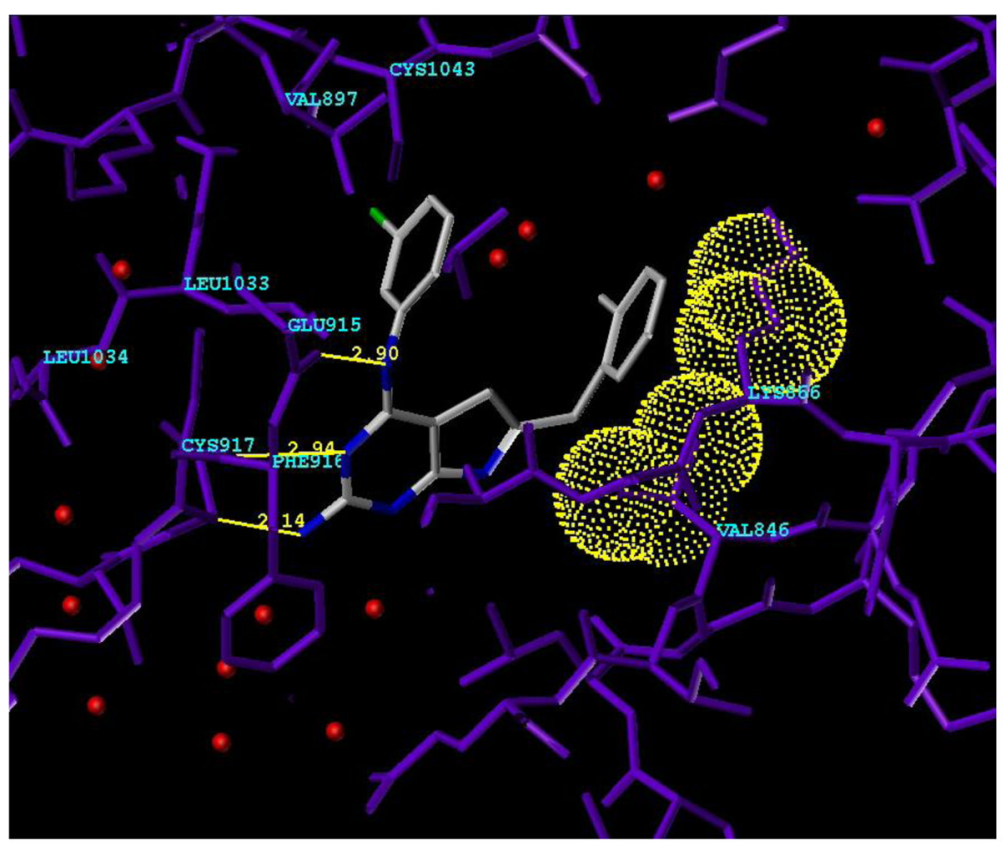

Figure 3.

Compound 5 in Mode 1 in VEGFR-2 (PDB code: 1YWN) showing the key interactions. Hydrogen bonding in the Hinge region between the 2- $\mathrm{NH}_{2}$ and the backbone carbonyl of Cys917, N3 and NH of Cys917 and 4-anilino NH and backbone carbonyl of Glu915. Hydrophobic interactions between the 4-anilino phenyl ring and Val897 and Cys1043 are indicated. Hydrophobic interactions between the 6-benzyl ring and Val846 and carbon chain of Lys866 (shown in dotted van der Waals surface for VEGFR-2). 


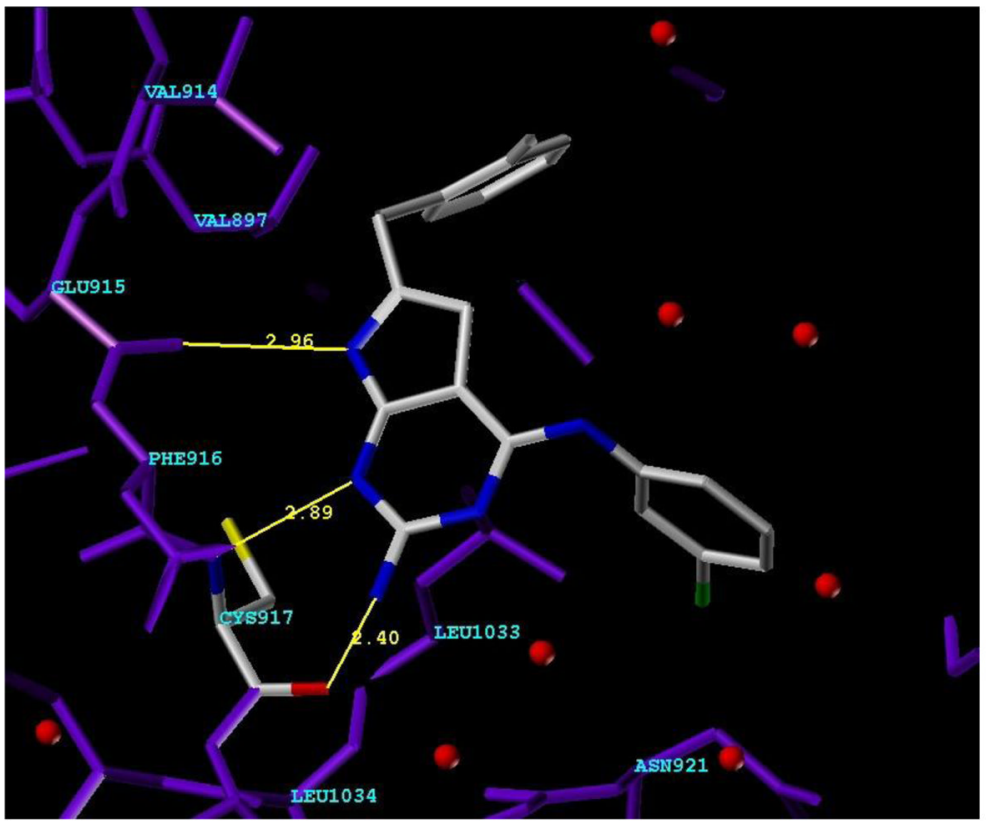

Figure 4.

Compound 5 in Mode 2 in VEGFR-2 (PDB code: 1YWN) showing hydrogen bonding in the Hinge region between the 2- $\mathrm{NH}_{2}$ and the backbone carbonyl of Cys917, N3 and NH of Cys917 and pyrrolo $\mathrm{NH}$ and backbone carbonyl of Glu915. 


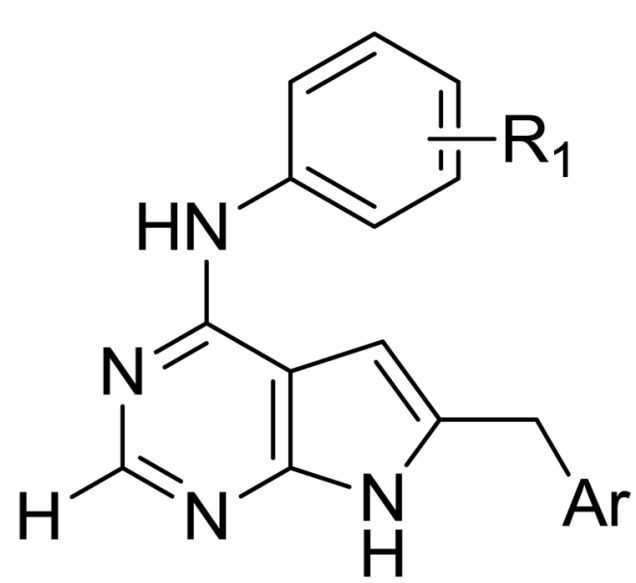

Figure 5.

$\begin{array}{lll} & \mathrm{R}_{1} & \mathrm{Ar} \\ 16 & 3-\mathrm{Br} & \text { 2-MePh } \\ 17 & 3-\mathrm{Br} & \text { 2,5-diOMePh } \\ 18 & 3-\mathrm{Br} & \text { 2,4-diCIPh } \\ 19 & 3-\mathrm{CF}_{3} & \text { 2,4-diCIPh } \\ 20 & 3-\mathrm{C} \equiv \mathrm{CH} & \text { 2,4-diCIPh }\end{array}$




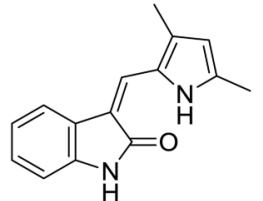

46, Semaxanib (SU5416)

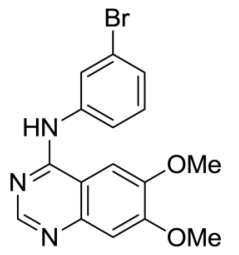

49, PD153035

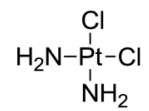

47, Cisplatin<smiles>CN(C)c1ccc(/C=C2\C(=O)Nc3ccccc32)cc1</smiles>

50, DMBI

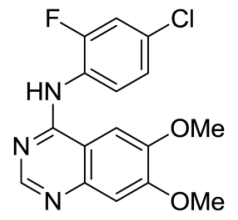

48. CB676475

Figure 6. 


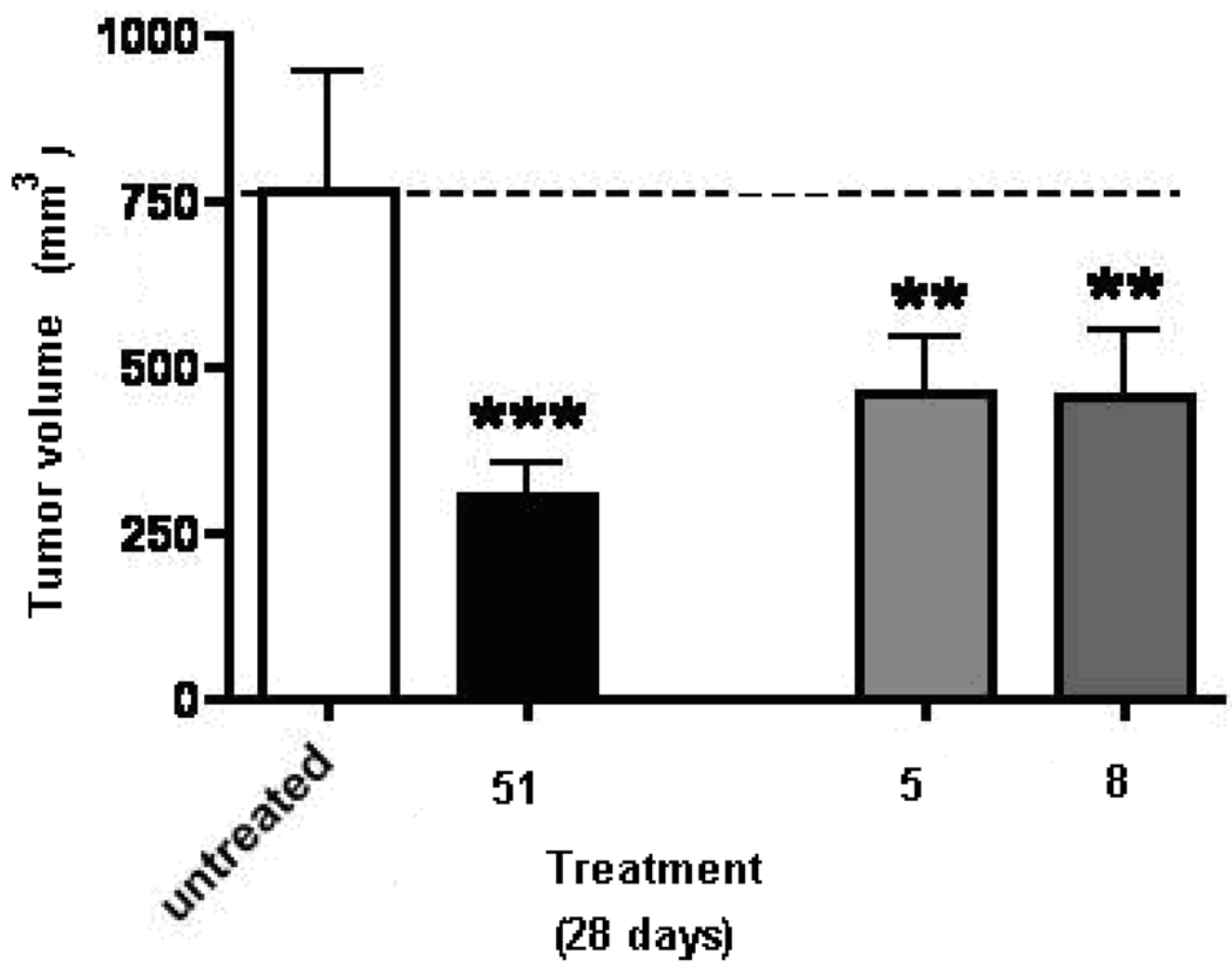

Figure 7.

Inhibitory activity of compounds $\mathbf{5 , 8}$ and $\mathbf{5 1}$ (SU6668) on primary tumor growth in the B16F10 melanoma model in mice, Values are mean \pm SEM., ${ }^{* * *}=\mathrm{P}<0.001,{ }^{* *}=\mathrm{P}<0.01$. 


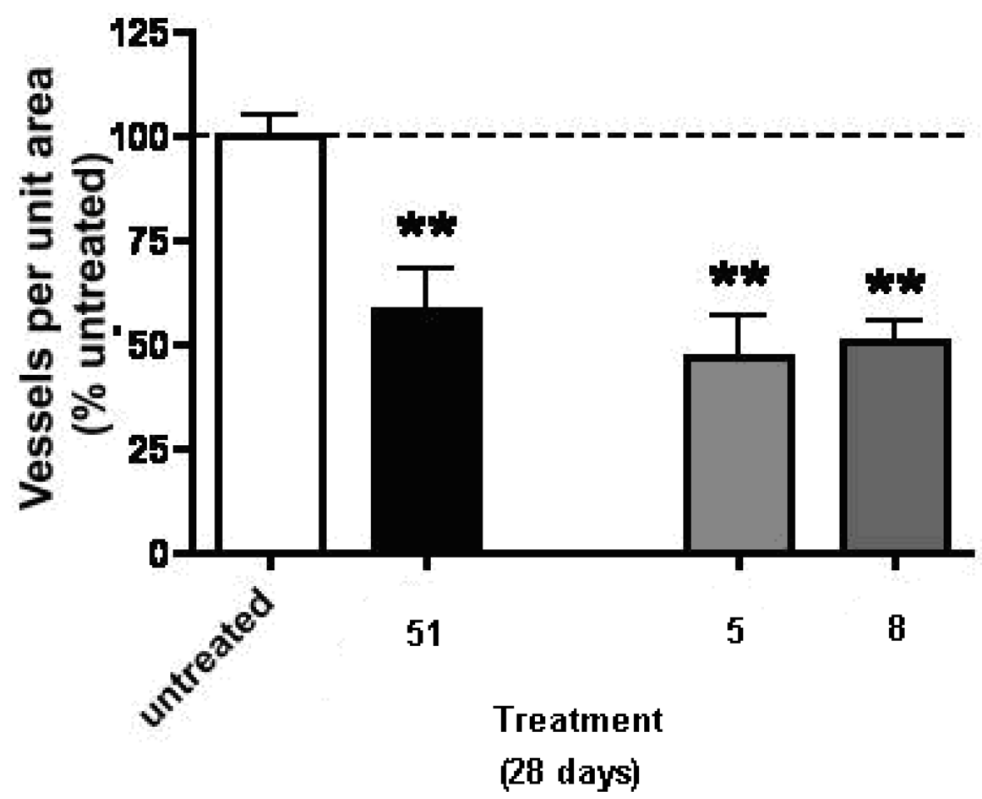

Figure 8.

The effect of compounds $\mathbf{5 , 8}$ and $\mathbf{5 1}$ (SU6668) on tumor vascularity in the B16-F10 melanoma model in mice, Values are mean \pm SEM., ${ }^{* *}=\mathrm{P}<0.01$. 


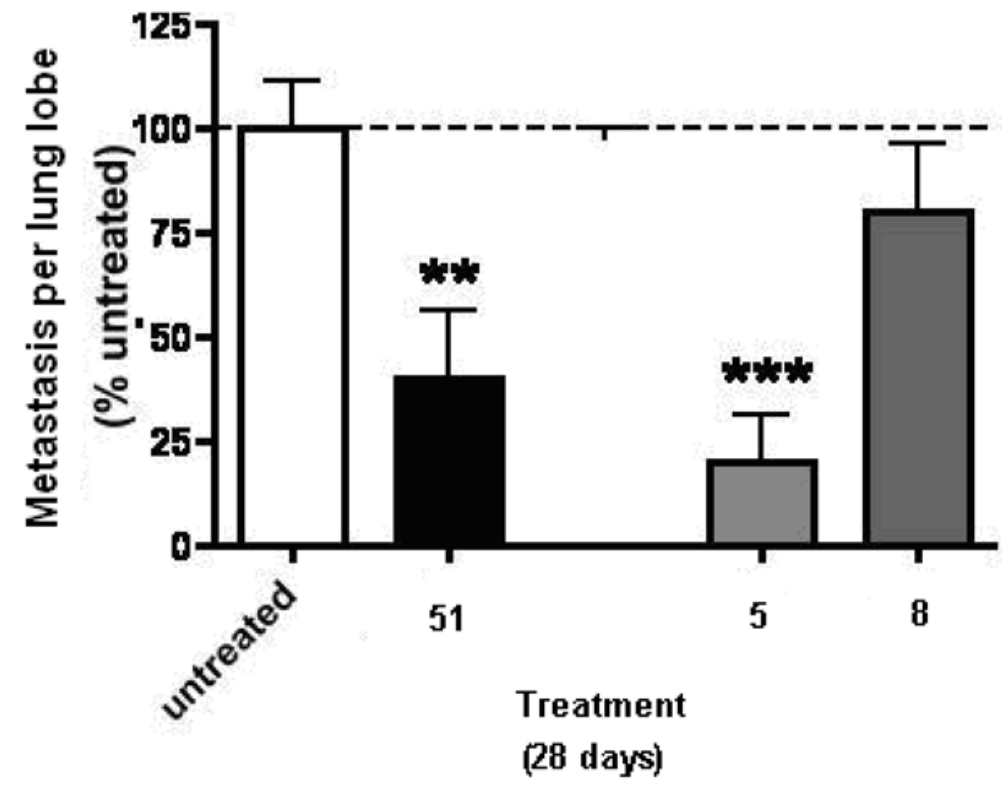

Figure 9.

The effect of compounds $\mathbf{5 , 8}$ and 51(SU6668) on tumor metastasis in the B16-F10 melanoma model in mice, Values are mean \pm SEM. ${ }^{* * *}=\mathrm{P}<0.001,{ }^{* *}=\mathrm{P}<0.01$. 

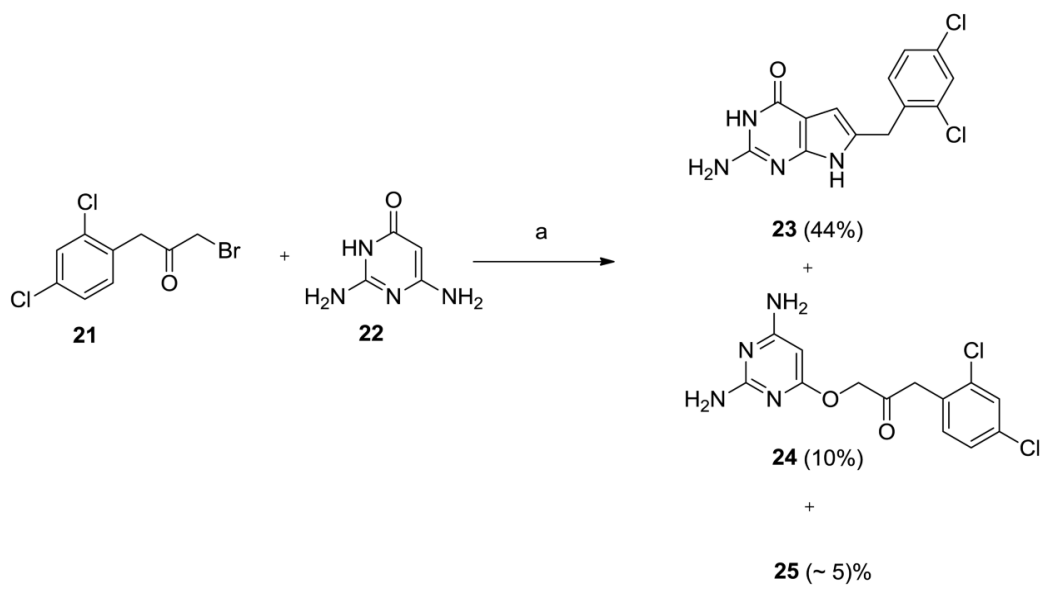

Scheme 1.

${ }^{a}$ Reagents and Conditions: (a) DMF, r.t., 3 days 

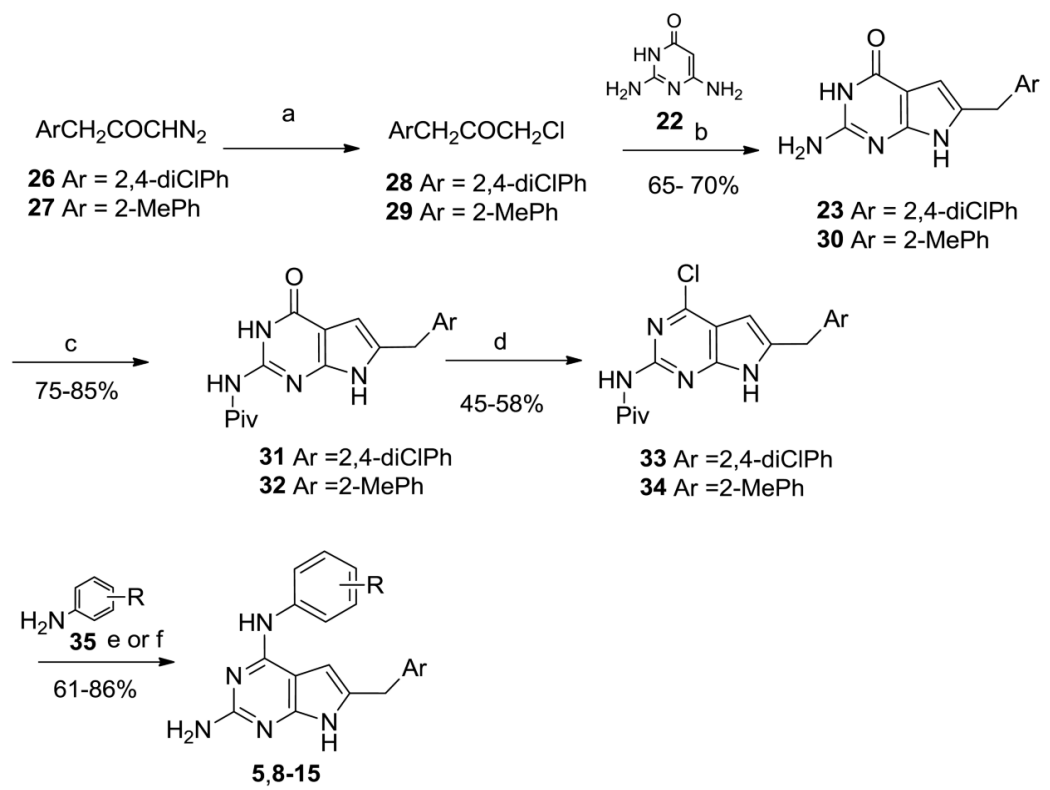

Scheme 2.

aReagents and Conditions: (a) conc $\mathrm{HCl}, 1 \mathrm{~h}, 70-80{ }^{\circ} \mathrm{C}$; (b) 21, $\mathrm{NaOAc}, \mathrm{H}_{2} \mathrm{O}, 12 \mathrm{~h}, 100{ }^{\circ} \mathrm{C}$; (c) $\mathrm{Piv}_{2} \mathrm{O}, 2 \mathrm{~h}, 120{ }^{\circ} \mathrm{C}$; (d) $\mathrm{POCl}_{3}, 3 \mathrm{~h}$, reflux; (e) 35, $i \mathrm{PrOH}, 2-3$ drops conc $\mathrm{HCl}, 16-48 \mathrm{~h}$, reflux; (f) 35, $i \mathrm{PrOH}, 2-3$ drops conc $\mathrm{HCl}$, microwave, 45 mins 


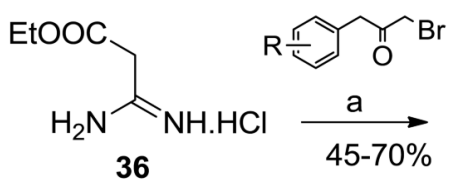<smiles>CCOC(=O)c1cc(C[Al])[nH]c1N</smiles><smiles>O=c1[nH]cnc2[nH]c(C[123I])cc12</smiles>

$37 \mathrm{Ar}=2-\mathrm{Me}$

$40 \mathrm{Ar}=2-\mathrm{Me}$

$38 \mathrm{Ar}=2,5-\mathrm{diOMe}$

$41 \mathrm{Ar}=2,5-\mathrm{diOMe}$

$39 \mathrm{Ar}=2,4-\mathrm{diCl}$

$42 \mathrm{Ar}=2,4-\mathrm{diC}$
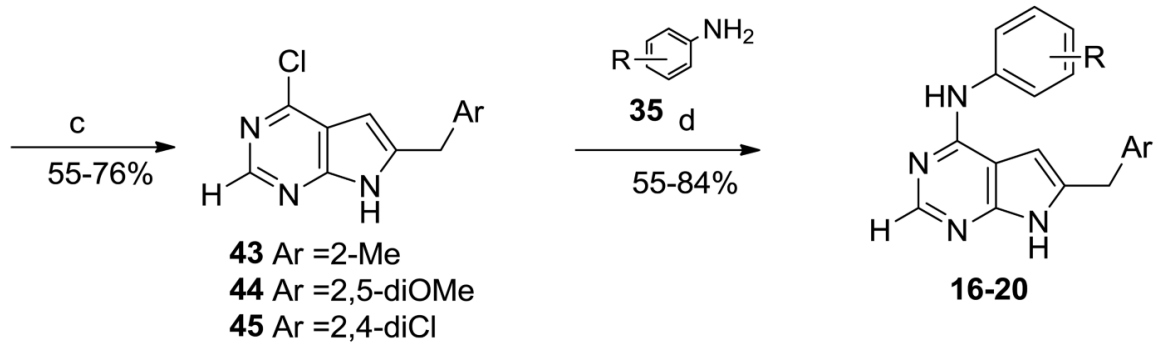

Scheme 3.

aReagents and Conditions: (a) $\alpha$-bromobenzylketones, EtOAc, $\mathrm{NEt}_{3}, \mathrm{~N}_{2}, 15$ mins, r.t. then 30 mins, (b) formamide, $\mathrm{Na} / \mathrm{MeOH}, 8 \mathrm{~h}, 120^{\circ} \mathrm{C}$; (c) $\mathrm{POCl}_{3}, 3 \mathrm{~h}$, reflux; (d) 35, $i \mathrm{PrOH}, 2-3$ drops conc $\mathrm{HCl}, 4$. 
